\title{
Solvation of Potassium 5-Hydroxy Pentanoyl Trifluoroborate Salt in Aqueous Environment by Using FT-Raman and UV-Visible Spectra
}

\author{
Maximiliano A. Iramain ${ }^{1}$, Elizabeth Imbarack ${ }^{2}$, Patricio Leyton Bongiorno ${ }^{2}$, \\ Emilio Lizarraga ${ }^{3}$, Silvia Antonia Brandán 1,* (D)
}

1 Cátedra de Química General, Instituto de Química Inorgánica, Facultad de Bioquímica, Química y Farmacia, Universidad Nacional de Tucumán, Ayacucho 471, 4000, Tucumán, Argentina; miramain9@ gmail.com (M.A.I.);

2 Laboratorio de Fotofísica y Espectroscopia Molecular No401, Av. Universidad \#330, Campus Curauma, Valparaíso, Pontificia Universidad Católica de Valparaíso, Chile; patricio.leyton@ pucv.cl (P.L.B.);

3 Instituto de Fisiología Animal, Fundación Miguel Lillo, Miguel Lillo 251, 4000, Tucumán, Argentina. Facultad de Ciencias Naturales e Instituto Miguel Lillo, Universidad Nacional de Tucumán, Miguel Lillo 205, 4000, Tucumán, Argentina; eflizarraga@lillo.org.ar (E.L.);

* Correspondence: brandansa@yahoo.com;

Scopus Author ID 6602262428

Received: 5.05.2021; Revised: 3.06.2021; Accepted: 6.06.2021; Published: 18.06.2021

Abstract: The hydration process of potassium 5-hydroxypentanoyltrifluoroborate salt, $\mathrm{K}_{2}\left[\mathrm{C}_{5} \mathrm{H}_{9} \mathrm{BF}_{3} \mathrm{O}_{2}\right]$ and its 5-hydroxypentanoyltrifluoroborate $\left[\mathrm{C}_{5} \mathrm{H}_{9} \mathrm{BF}_{3} \mathrm{O}_{2}\right]^{-}$anion have been studied by combining the experimental FT-Raman and ultraviolet-visible spectra in aqueous solution with hybrid B3LYP/6$311++G^{* *}$ calculations. Solvent effects have been considered with the self-consistent reaction field (SCRF) and solvation (SM) models. Here, the structures of $\left[\mathrm{C}_{5} \mathrm{H}_{9} \mathrm{BF}_{3} \mathrm{O}_{2}\right] \cdot\left[\mathrm{H}_{2} \mathrm{O}\right]_{\mathrm{n}}$ clusters of anion, with $\mathrm{n}$ from 1 to 5 implicit water molecules, were proposed in order to study the number of water molecules that could hydrate the anion. Calculations were performed in the gas phase and an aqueous solution to observe the effect of the medium on the dipole moment and volume values. Calculated solvation energies for all clusters were corrected by zero-point vibrational energy (ZPVE), non-electrostatic terms and by basis set superposition energy (BSSE). The dipole moment of salt in solution (10.19 D) suggests that the number of water molecules that could hydrate the anion vary between 3 and 4 , in total agreement with the observed and predicted bands in the UV-Vis spectra for the salt and these two clusters in water between 180 and $400 \mathrm{~nm}$. Comparisons among experimental and predicted Raman spectra show clearly the hydration effect because the bands attributed to $\mathrm{OH}, \mathrm{BF}_{3}$ and $\mathrm{C}=\mathrm{O}$ groups are shifted in solution, while, the predicted Raman spectra for all clusters in solution show strong changes in the intensities of many bands, in accordance with the corresponding experimental one. Evidently, the hydration occurs on the $\mathrm{OH}, \mathrm{BF}_{3}$ and $\mathrm{C}=\mathrm{O}$ groups.

Keywords: potassium 5-hydroxypentanoyltrifluoroborate salt; molecular structure; DFT calculations.

(c) 2021 by the authors. This article is an open-access article distributed under the terms and conditions of the Creative Commons Attribution (CC BY) license (https://creativecommons.org/licenses/by/4.0/).

\section{Introduction}

The combinations of experimental studies in solution with theoretical calculations of different species greatly aid in analyzing their stabilities and predicting properties and behaviors because many times, the structures undergo important changes with the medium and especially in aqueous solution [1-3]. In particular, the potassium trifluoroborate salts are structurally interesting due to the versatility of trifluoroborate group to form 3D structures with different behaviors and coordination modes that result from an interest in the supramolecular 
chemistry and in the design of new materials [4-11]. Hence, due to the characteristics of different $\mathrm{C}-\mathrm{H} \cdots \mathrm{F}$ and $\mathrm{B}-\mathrm{F}$ bonds, these potassium trifluoroborate salts are excellent reagents in organic synthesis chemistry [12-18]. Besides, the theoretical studies on these salts greatly aid in investigating how the different groups linked to trifluoroborate influence their reactivities and structural, electronic, topological and vibrational properties [7-11]. Some experimental studies on these salts have suggested that steric and conformational factors modulate their reactivities in solution [12-18]. Hence, it is of great interest to elucidate the number of water molecules surrounding the potassium 5-hydroxypentanoyltrifluoroborate salt, $\mathrm{K}\left[\mathrm{C}_{5} \mathrm{H}_{9} \mathrm{BF}_{3} \mathrm{O}_{2}\right]$ (HTFB), in an aqueous environment. This way, the purposes of this work were: (i) to study theoretically clusters of 5-hydroxypentanoyltrifluoroborate anion, $\left[\mathrm{C}_{5} \mathrm{H}_{9} \mathrm{BF}_{3} \mathrm{O}_{2}\right] \times\left[\mathrm{H}_{2} \mathrm{O}\right]_{n}$ with different numbers of implicit $n$ water molecules, from 1 to 5, in the gas phase and aqueous solution because it species is present when the salt is dissolved in water, (ii) to calculate the solvation energies of each cluster in order to predict the number of water molecules that can hydrate to $\left[\mathrm{C}_{5} \mathrm{H}_{9} \mathrm{BF}_{3} \mathrm{O}_{2}\right]^{-}$anion, (iii) to analyze the changes performed in the experimental Raman spectrum in aqueous solution and to compare with that experimental previously reported for this salt in the solid phase and also to analyze the experimental ultraviolet, visible spectrum in aqueous solution and finally, (iv) to predict the reactivities and behaviors of different clusters in water and, to compare with the values previously reported for the salt [9] by using the hybrid B3LYP/6-311++G** level of theory $[19,20]$. In an aqueous solution, the $\left[\mathrm{C}_{5} \mathrm{H}_{9} \mathrm{BF}_{3} \mathrm{O}_{2}\right] \times\left[\mathrm{H}_{2} \mathrm{O}\right]_{n}$ clusters were modeled and optimized by using the integral equation formalism variant polarised continuum method (IEFPCM) [21,22], while, their solvation energies were calculated employing the universal solvation model at the same level of theory [23]. The dipole moment and volume values and solvation energies of different clusters in the gas phase and aqueous solution were represented as functions of a number of implicit water molecules following that methodology employed for phosphate ions in water [24]. The complete vibrational analyses of salt in aqueous solution were performed with the harmonic force fields and the Molvib program following the scaled quantum mechanical force field (SQMFF) procedure, as reported in the previous study $[9,25,26]$. Here, the determination of the number of water molecules around the anion was carrying out considering different relationships between the volumes of clusters and the solvation energies, taking into account the number of water molecules, as in the methodology employed for phosphate anions in water [24].

\section{Materials and Methods}

\subsection{Experimental.}

The FT-Raman spectra were recorded using a Wintec Alpha 300 confocal Raman microscope system equipped using an excitation laser wavelength of $785 \mathrm{~nm}$ and an electrically cooled CCD camera. The signal was calibrated using the $520 \mathrm{~cm}^{-1}$ lines of a-Si wafer and a 20x objective. The laser power on the samples was $2 \mathrm{~mW}$. The resolution was set to $4 \mathrm{~cm}^{-1}$ and 10 scans with an integration time of $1 \mathrm{~s}$ were performed. The spectra were recorded over the 200$1800 \mathrm{~cm}^{-1}$ region.

Beckman spectrophotometer was used to record the electronic spectrum of PTFB in an aqueous solution between 180 and $800 \mathrm{~nm}$.

The UV-Visible measurements were recorded using quartz cells $(10 \mathrm{~mm}$ optical path length) in a Specord S-600 diode array spectrophotometer. For this purpose, a solution of 9.84 
$\mathrm{mg} / \mathrm{L}$ of compounds in water was prepared. Each spectrum was recorded between 182 and 400 $\mathrm{nm}$ region.

\subsection{Computational details.}

The initial structures of the different $\left[\mathrm{C}_{5} \mathrm{H}_{9} \mathrm{BF}_{3} \mathrm{O}_{2}\right] \cdot\left[\mathrm{H}_{2} \mathrm{O}\right]_{n}$ clusters with implicit $\mathrm{n}$ water molecules, from 1 to 5, were modeled with the Hyperchem program [27]. The modifications of several water molecules were carried out with the GaussView program [28]. The optimizations of all systems were performed in the gas phase and in an aqueous solution by using the hybrid B3LYP/6-311++G** method [19,20] and the Revision A.02 of the Gaussian 09 program [29]. The integral equation formalism variant polarised continuum method (IEFPCM) was employed for all calculations in solution [21,22], while the volume values were calculated with the Moldraw program [30]. The gap values for all clusters in both media were calculated with the frontier orbitals by using the hybrid B3LYP/6-311++G** method [16,17], as recommended by Parr and Pearson [31]. Then, the chemical potential $(\mu)$, electronegativity $(\chi)$, global hardness $(\eta)$, global softness $(S)$, global electrophilicity index $(\omega)$ and nucleophilicity indexes $(E)$ descriptors were employed to predict the behaviors of clusters in the two media [32-36]. The standard Boys-Bernardi counterpoise method by basis set superposition error (BSSE) was employed to correct the solvation energies of $\left[\mathrm{C}_{5} \mathrm{H}_{9} \mathrm{BF}_{3} \mathrm{O}_{2}\right] .\left(\mathrm{H}_{2} \mathrm{O}\right)_{n}$ clusters from 1 to $n$ water molecules [37]. The predicted Raman spectra in activities were

\section{Results and Discussion}

\subsection{Geometries of clusters in gas and aqueous solution.}

The optimized structures of $\mathrm{K}\left[\mathrm{C}_{5} \mathrm{H}_{9} \mathrm{BF}_{3} \mathrm{O}_{2}\right](\mathrm{HTFB})$ salt and its $\left[\mathrm{C}_{5} \mathrm{H}_{9} \mathrm{BF}_{3} \mathrm{O}_{2}\right]^{-}$anion can be seen in Figure 1 together with the atoms labeling, while in Figure 2 are presented the $\left[\mathrm{C}_{5} \mathrm{H}_{9} \mathrm{BF}_{3} \mathrm{O}_{2}\right] \times\left[\mathrm{H}_{2} \mathrm{O}\right]_{n}$ clusters of the anion with $\mathrm{n}$ water molecules where $\mathrm{n}$ varies from 1 to 5 , showing the different $\mathrm{H}$ bonds interactions.

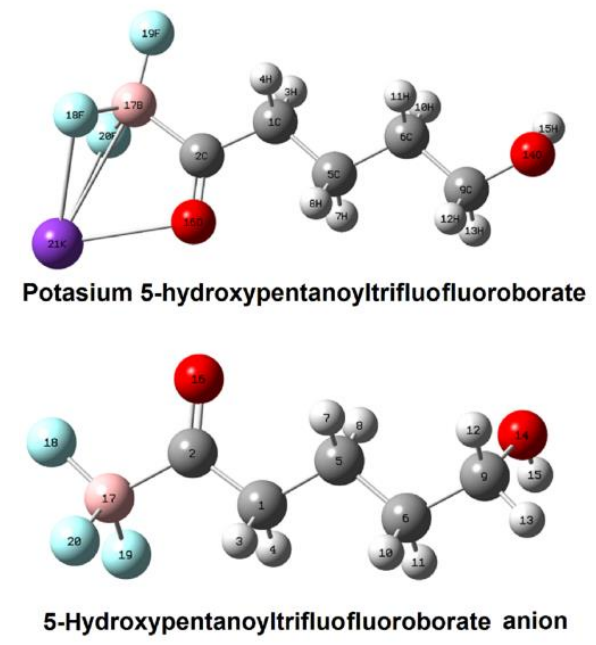

Figure 1. Molecular structures of the $\mathrm{K}\left[\mathrm{C}_{5} \mathrm{H}_{9} \mathrm{BF}_{3} \mathrm{O}_{2}\right]$ salt and its 5-hydroxypentanoyltrifluoroborate $\left[\mathrm{C}_{5} \mathrm{H}_{9} \mathrm{BF}_{3} \mathrm{O}_{2}\right]^{-}$anion in aqueous solution by using B3LYP/6-311++ $\mathrm{G}^{* *}$ level of theory and atoms numbering. 


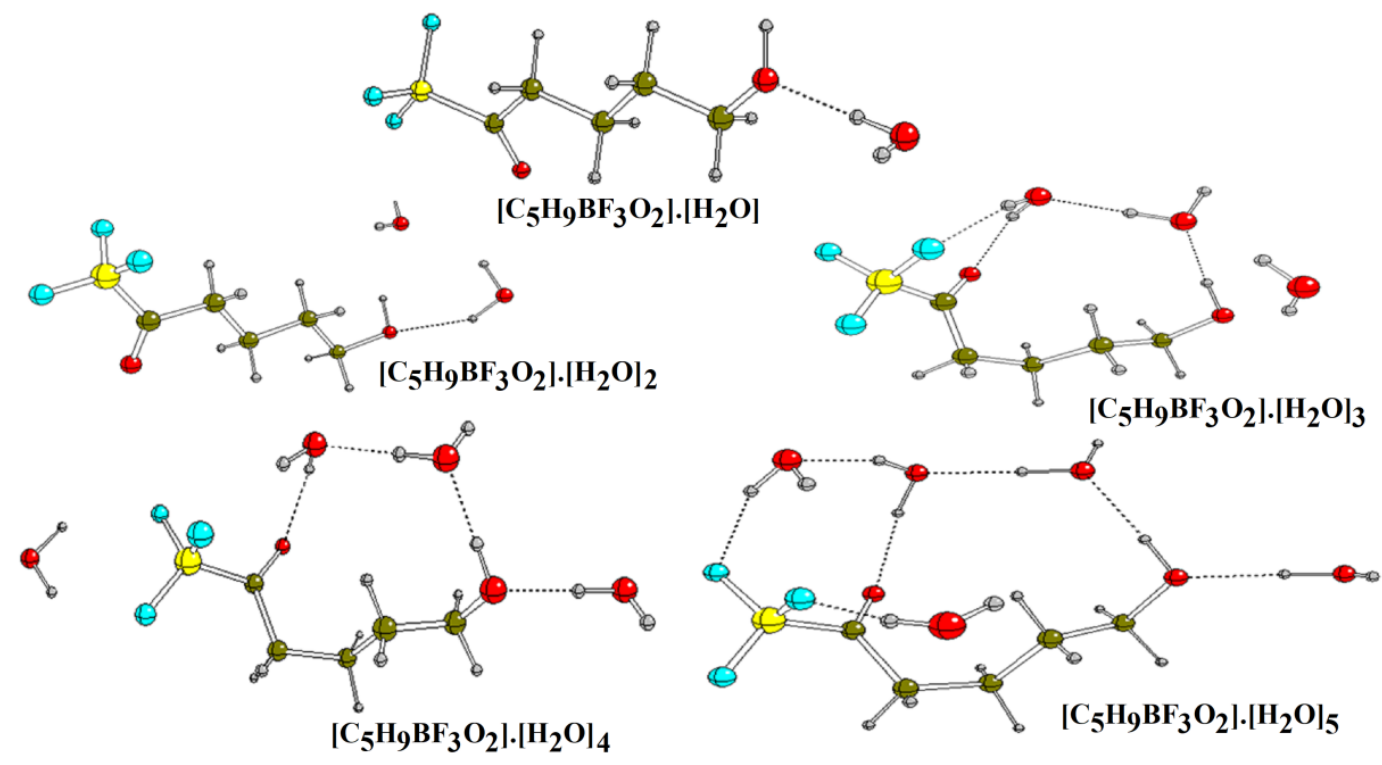

Figure 2. Molecular structures of the $\left[\mathrm{C}_{5} \mathrm{H}_{9} \mathrm{BF}_{3} \mathrm{O}_{2}\right] \cdot\left[\mathrm{H}_{2} \mathrm{O}\right]_{\mathrm{n}}$ clusters of 5-hydroxypentanoyltrifluoroborate $\left[\mathrm{C}_{5} \mathrm{H}_{9} \mathrm{BF}_{3} \mathrm{O}_{2}\right]^{-}$anion in the gas phase using the B3LYP/6-311++G** level of theory.

Calculated uncorrected and corrected total energy by ZPVE and by BSSE (E), dipole moments and molecular volumes for the clusters of 5-hydroxypentanoyltrifluoroborate $\left[\mathrm{C}_{5} \mathrm{H}_{9} \mathrm{BF}_{3} \mathrm{O}_{2}\right]^{-}$anion with $\mathrm{n}$ water molecules in the gas phase and aqueous solution by using B3LYP/6-311++G** level of theory can be seen in Table 1 . The values corresponding to the salt were included because, in an aqueous solution, the salt is dissociated as anion and cation and, for this reason, the dipole moment value and the volume change with the media. Note that the $\mathrm{BSSE}^{\#}$ values presented in column 5 for all clusters practically do not change, although few variations in the corresponding dipole moment values in column 6 are observed. Figure $3 \mathrm{a}$ shows the behaviors of dipole moment values for all clusters in gas and aqueous solution, including the observed only for the anion versus the number of water molecules. In both media, the dipole moment values decrease when increasing the number of water molecules, but the dipole moment values when the energies are corrected by BSSE slightly increase only for the clusters with 4 and 5 water molecules. In the four cases analyzed, the cluster with 2 water molecules presents the higher dipole moment value in the two media studied. Then, when the solvation energies are analyzed with the number of water molecules, we observed that the higher dipole moment value corresponds to the higher solvation energy for the cluster with 2 water molecules. Suppose now we analyze the volume's values for all clusters from Figure 3b, including the anion in both media, in the function of a number of water molecules. In that case, it is observed a lineal tendency with a reasonable correlation factor of 0.9863 in an aqueous solution. Thus, the volume of clusters $(\mathrm{V})$ in an aqueous solution relates to the number of water molecules $\mathrm{N}$ by the following relationship: (1) $\mathrm{V}=21.463 \mathrm{~N}+170.78$. Considering $\mathrm{V}$ of salt of $252.9 \AA^{3}$ in the gas phase and $255.7 \AA^{3}$ in aqueous solution, the number of water molecules that can hydrate to the salt in both media is approximately 4 water molecules. If now, the uncorrected and corrected solvation energies $(\Delta \mathrm{G})$ by ZPVE and by BSSE are analyzed for all clusters, including the anion as a function of several water molecules from Table 2 and Figure 4, different behaviors are observed. 
Table 1. Calculated uncorrected and corrected total energy by ZPVE and by BSSE $(E)$, dipole moments and molecular volumes for the clusters of 5hydroxypentanoyltrifluoroborate $\left[\mathrm{C}_{5} \mathrm{H}_{9} \mathrm{BF}_{3} \mathrm{O}_{2}\right]^{-}$anion with $\mathrm{n}$ water molecules in the gas phase and aqueous solution by using $\mathrm{B} 3 \mathrm{LYP} / 6-311++\mathrm{G}^{* *}$ level of theory.

B3LYP/6-311++G** method

GAS-PHASE

\begin{tabular}{|c|c|c|c|c|c|c|c|}
\hline Clusters & $\mathbf{E}$ & E (ZPVE) & $\mu$ & $\mathbf{V}$ & BSSE $^{\#}$ & $\mu^{\#}$ & $\mathrm{BSSE}+\mathbf{n}\left(\mathrm{H}_{2} \mathrm{O}\right)$ \\
\hline$\left(\mathrm{H}_{2} \mathrm{O}\right)$ & -76.4585 & -76.4372 & 2.16 & 29.3 & & & \\
\hline $\mathrm{K}\left[\mathrm{C}_{5} \mathrm{H}_{9} \mathrm{BF}_{3} \mathrm{O}_{2}\right]$ & -1271.1848 & & 8.40 & 252.9 & & & \\
\hline$\left[\mathrm{C}_{5} \mathrm{H}_{9} \mathrm{BF}_{3} \mathrm{O}_{2}\right]^{-}$ & -671.2398 & -671.0926 & 10.18 & 169.6 & & 10.18 & \\
\hline$\left[\mathrm{C}_{5} \mathrm{H}_{9} \mathrm{BF}_{3} \mathrm{O}_{2}\right] \cdot\left(\mathrm{H}_{2} \mathrm{O}\right)$ & -747.7130 & -747.5415 & 10.85 & 186.6 & -671.2407 & 12.6 & -747.6779 \\
\hline$\left[\mathrm{C}_{5} \mathrm{H}_{9} \mathrm{BF}_{3} \mathrm{O}_{2}\right] \cdot\left(\mathrm{H}_{2} \mathrm{O}\right)_{2}$ & -824.1785 & -823.9824 & 11.36 & 213.3 & -671.2421 & 14.63 & -824.1168 \\
\hline$\left[\mathrm{C}_{5} \mathrm{H}_{9} \mathrm{BF}_{3} \mathrm{O}_{2}\right] \cdot\left(\mathrm{H}_{2} \mathrm{O}\right)_{3}$ & -900.6787 & -900.4543 & 5.50 & 237.3 & -671.2405 & 9.59 & -900.5521 \\
\hline$\left[\mathrm{C}_{5} \mathrm{H}_{9} \mathrm{BF}_{3} \mathrm{O}_{2}\right] \cdot\left(\mathrm{H}_{2} \mathrm{O}\right)_{4}$ & -977.1548 & -976.9070 & 4.89 & 247.6 & -671.2409 & 8.79 & -976.9897 \\
\hline$\left[\mathrm{C}_{5} \mathrm{H}_{9} \mathrm{BF}_{3} \mathrm{O}_{2}\right] \cdot\left(\mathrm{H}_{2} \mathrm{O}\right)_{5}$ & -1053.6312 & -1053.3582 & 2.98 & 279.9 & -671.2419 & 10.20 & -1053.4279 \\
\hline \multicolumn{8}{|c|}{ AQUEOUS SOLUTION } \\
\hline
\end{tabular}

\begin{tabular}{|c|c|c|c|c|c|c|c|}
\hline$\left(\mathrm{H}_{2} \mathrm{O}\right)$ & -76.4721 & -76.4511 & 2.64 & 29.3 & & & \\
\hline $\mathrm{K}\left[\mathrm{C}_{5} \mathrm{H}_{9} \mathrm{BF}_{3} \mathrm{O}_{2}\right]$ & -1271.2180 & & 10.19 & 255.7 & & & \\
\hline$\left[\mathrm{C}_{5} \mathrm{H}_{9} \mathrm{BF}_{3} \mathrm{O}_{2}\right]^{-}$ & -671.3362 & -671.1889 & 13.91 & 170.0 & & 13.91 & \\
\hline$\left[\mathrm{C}_{5} \mathrm{H}_{9} \mathrm{BF}_{3} \mathrm{O}_{2}\right] .\left(\mathrm{H}_{2} \mathrm{O}\right)$ & -747.8139 & -747.6424 & 13.10 & 190.3 & -671.3343 & 14.64 & -747.7854 \\
\hline$\left[\mathrm{C}_{5} \mathrm{H}_{9} \mathrm{BF}_{3} \mathrm{O}_{2}\right] .\left(\mathrm{H}_{2} \mathrm{O}\right)_{2}$ & -824.2888 & -824.0936 & 17.22 & 216.4 & -671.3315 & 16.54 & -824.2337 \\
\hline$\left[\mathrm{C}_{5} \mathrm{H}_{9} \mathrm{BF}_{3} \mathrm{O}_{2}\right] \cdot\left(\mathrm{H}_{2} \mathrm{O}\right)_{3}$ & -900.7689 & -900.5489 & 9.18 & 240.9 & -671.3287 & 10.74 & -900.6876 \\
\hline$\left[\mathrm{C}_{5} \mathrm{H}_{9} \mathrm{BF}_{3} \mathrm{O}_{2}\right] \cdot\left(\mathrm{H}_{2} \mathrm{O}\right)_{4}$ & -977.2444 & -977.0013 & 8.77 & 248.7 & -671.3271 & 10.12 & -977.1315 \\
\hline$\left[\mathrm{C}_{5} \mathrm{H}_{9} \mathrm{BF}_{3} \mathrm{O}_{2}\right] .\left(\mathrm{H}_{2} \mathrm{O}\right)_{5}$ & -1053.7260 & -1053.4578 & 5.87 & 280.3 & -671.3375 & 11.36 & -1053.5930 \\
\hline
\end{tabular}

\#Corrected by BSSE by Ref [34]. 
Table 2. Corrected and uncorrected solvation energies by the total non-electrostatic terms by zero-point vibrational energy (ZPVE) and by BSSE for the clusters of 5hydroxypentanoyltrifluoroborate $\left[\mathrm{C}_{5} \mathrm{H}_{9} \mathrm{BF}_{3} \mathrm{O}_{2}\right]^{-}$anion with $\mathrm{n}$ water molecules in aqueous solution by using B3LYP/6-311++G** level of theory.

\begin{tabular}{|c|c|c|c|c|c|c|c|c|}
\hline \multicolumn{9}{|c|}{ B3LYP/6-311++G** method } \\
\hline Solvation energy & $\mathbf{E}$ & E (ZPVE) & $\mathrm{BSSE}+\mathbf{n}\left(\mathrm{H}_{2} \mathrm{O}\right)$ & PCM & $\mathbf{E}$ & E (ZPVE) & $\mathrm{BSSE}+\mathbf{n}\left(\mathrm{H}_{2} \mathrm{O}\right)$ & $\Delta \mathbf{V}$ \\
\hline Anion & $\Delta \mathbf{G}_{\text {un }}$ & $\Delta \mathbf{G}_{\text {un }}$ & $\Delta \mathbf{G}_{\text {un }}$ & $\Delta \mathbf{G}_{\mathbf{n e}}$ & $\Delta \mathbf{G}_{\mathbf{c}}$ & $\Delta \mathbf{G}_{\mathbf{c}}$ & $\Delta \mathbf{G}_{\mathbf{c}}$ & $\Delta \mathbf{V}$ \\
\hline$\left(\mathrm{H}_{2} \mathrm{O}\right)$ & -35.67 & -36.75 & & 6.10 & -41.77 & -42.85 & & 0.0 \\
\hline$\left[\mathrm{C}_{5} \mathrm{H}_{9} \mathrm{BF}_{3} \mathrm{O}_{2}\right]^{-}$ & -252.86 & -259.59 & & 25.37 & -283.73 & -284.52 & & 0.4 \\
\hline$\left[\mathrm{C}_{5} \mathrm{H}_{9} \mathrm{BF}_{3} \mathrm{O}_{2}\right] \cdot\left(\mathrm{H}_{2} \mathrm{O}\right)$ & -264.66 & -264.65 & -281.97 & 29.60 & -294.96 & -294.95 & -252.37 & 3.7 \\
\hline$\left[\mathrm{C}_{5} \mathrm{H}_{9} \mathrm{BF}_{3} \mathrm{O}_{2}\right] .\left(\mathrm{H}_{2} \mathrm{O}\right)_{2}$ & -289.32 & -291.68 & -306.63 & 32.60 & -321.92 & -324.28 & -339.23 & 3.1 \\
\hline$\left[\mathrm{C}_{5} \mathrm{H}_{9} \mathrm{BF}_{3} \mathrm{O}_{2}\right] \cdot\left(\mathrm{H}_{2} \mathrm{O}\right)_{3}$ & -236.56 & -248.14 & -355.42 & 32.98 & -269.54 & -281.12 & -388.40 & 3.6 \\
\hline$\left[\mathrm{C}_{5} \mathrm{H}_{9} \mathrm{BF}_{3} \mathrm{O}_{2}\right] \cdot\left(\mathrm{H}_{2} \mathrm{O}\right)_{4}$ & -235.02 & -247.35 & -371.94 & 33.98 & -269.00 & -281.33 & -405.92 & 1.1 \\
\hline$\left[\mathrm{C}_{5} \mathrm{H}_{9} \mathrm{BF}_{3} \mathrm{O}_{2}\right] \cdot\left(\mathrm{H}_{2} \mathrm{O}\right)_{5}$ & -248.66 & -261.25 & -433.06 & 34.65 & -283.31 & -295.90 & -467.71 & 0.4 \\
\hline
\end{tabular}

${ }^{\#} \mathrm{AS}-\mathrm{GP}=$ Aqueous solution - Gas phase

$\Delta \mathrm{G}_{\mathrm{un}}=$ uncorrected solvation energy, $\Delta \mathrm{G}_{\mathrm{ne}}=$ total non-electrostatic terms, $\Delta \mathrm{G}_{\mathrm{c}}=$ corrected solvation energies 

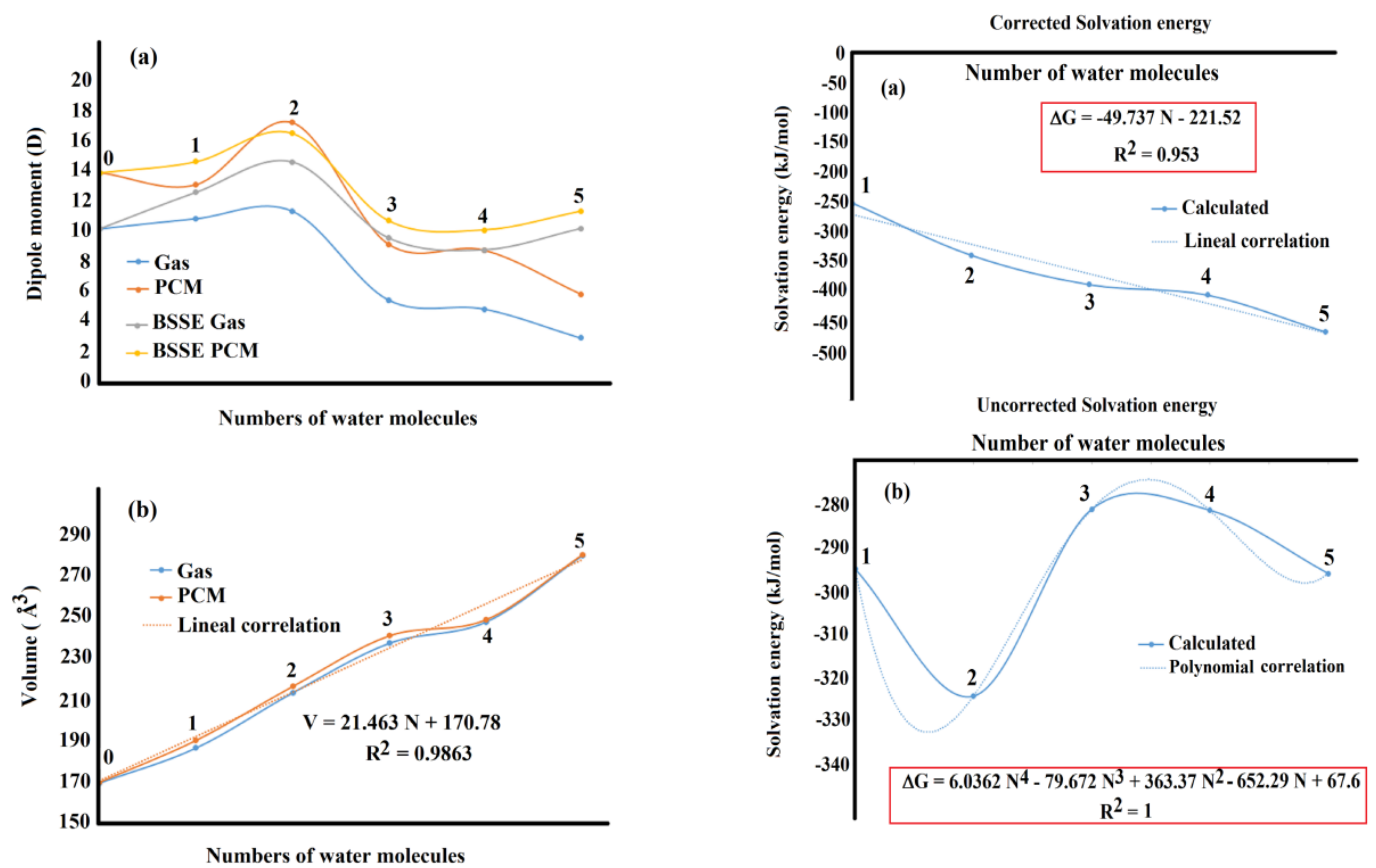

Figure 3. (a) Behaviours of dipole moment and (b) volumes values of $\left[\mathrm{C}_{5} \mathrm{H}_{9} \mathrm{BF}_{3} \mathrm{O}_{2}\right] \cdot\left[\mathrm{H}_{2} \mathrm{O}\right]_{\mathrm{n}}$ clusters and the 5-hydroxypentanoyltrifluoroborate $\left[\mathrm{C}_{5} \mathrm{H}_{9} \mathrm{BF}_{3} \mathrm{O}_{2}\right]^{-}$anion with the number of water molecules in the gas phase and aqueous solution by using the B3LYP/6-311++G** level of theory.

Figure 4. (a) Corrected and (b) uncorrected solvation energies of $\left[\mathrm{C}_{5} \mathrm{H}_{9} \mathrm{BF}_{3} \mathrm{O}_{2}\right] \cdot\left[\mathrm{H}_{2} \mathrm{O}\right]_{\mathrm{n}}$ clusters and the 5-hydroxypentanoyltrifluoroborate $\left[\mathrm{C}_{5} \mathrm{H}_{9} \mathrm{BF}_{3} \mathrm{O}_{2}\right]^{-}$anion with the number of water molecules in the gas phase and aqueous solution by using the B3LYP/6-311++G** level of theory.

Thus, a lineal tendency is observed when the values are corrected (Fig. 4a) by ZPVE and by BSSE with a reasonable correlation factor of 0.953 , being the solvation energy related by the equation (2): $\Delta \mathrm{G}=-49.737 \mathrm{~N}-221.52$ where $\mathrm{N}$ is the number of water molecules. On the contrary, when the values are uncorrected by BSSE (Fig. 4b), a polynomial correlation with an excellent coefficient of 1 is observed. In this case, the polynomial equation found between $\Delta \mathrm{G}$ and $\mathrm{N}$ are as follows: (3) $\Delta \mathrm{G}=6.0362 \mathrm{~N}^{4}-79.672 \mathrm{~N}^{3}+363.37 \mathrm{~N}^{2}-652.29 \mathrm{~N}+67.6$. With the solvation energy value of anion of $-284.52 \mathrm{~kJ} / \mathrm{mol}$ it is possible to calculate from equations (2) and (3) the value of $\mathrm{N}$; hence, the value is approximately 1 , for which only one water molecule could solvate the anion. On the other hand, the most negative solvation energy not corrected by BSSE (Fig. 4b) is observed for the cluster with 2 water molecules justifying. This way, the observed higher dipole moment value for this cluster is observed in Figure $3 a$. Analyzing the obtained results exhaustively for the salt and its anion, we observed important differences in the numbers of water molecules because superficially, from 1 or 4 , water molecules could hydrate the anion.

Apparently, there is not found a reasonable explanation for this variation. However, when the volume variations observed for all clusters from Table 2 are deeply evaluated as a function of the water molecules, we observed that the anion without water molecule has the same $\mathrm{V}$ variation as the cluster with five water molecules, which is $0.4 \AA^{3}$. Later, when these values are graphed in Figure 5, it is possible to observe that for a value of $\mathrm{V}$, two values of $\mathrm{N}$ are observed. Thus, these $\Delta \mathrm{V}$ values suggest that probably the number of water molecules that hydrate the anion could vary between two values. Hence, if the salt presents a $\mathrm{V}$ variation of $2.8 \AA^{3}$ (255.7-252.9 $\AA^{3}$ from Table 1$)$, the number of water molecules in the anion only will be possible only between 3 or 4 . On the other hand, Figure 2 shows clearly that from 1 to 2 water molecules, the $\mathrm{OH}$ groups hydrate mainly the anion, while after three water molecules, in 
addition, the other $\mathrm{C}=\mathrm{O}$ and $\mathrm{BF}_{3}$ groups are also solvated. Possibly, this higher hydration of groups generates a decrease in the $\mathrm{V}$ of the salt and an increase in the dipole moment value from $8.40 \mathrm{D}$ in the gas phase to 10.19 $\mathrm{D}$ in an aqueous solution. Hence, from Figure 3 is easily seen that with the dipole moment of salt has a value of $10.19 \mathrm{D}$, the number of water molecules in the anion can vary between 3 and 4 (orange line on Fig. 3).

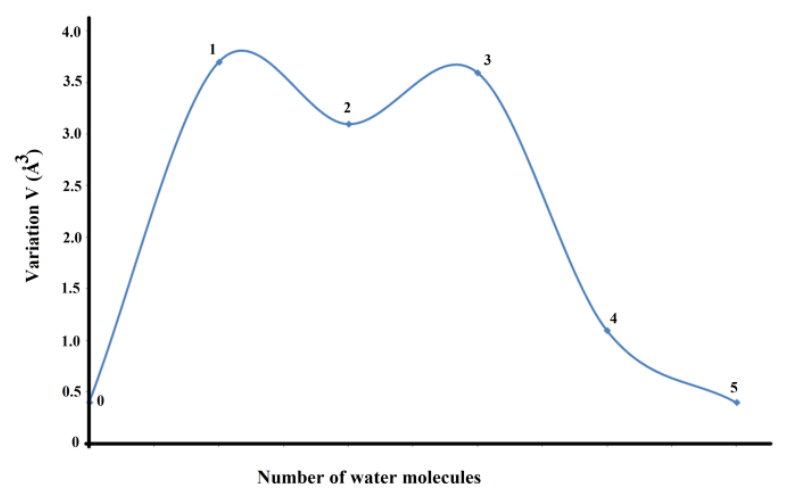

Figure 5. Volumes variations of $\left[\mathrm{C}_{5} \mathrm{H}_{9} \mathrm{BF}_{3} \mathrm{O}_{2}\right] .\left[\mathrm{H}_{2} \mathrm{O}\right]_{n}$ clusters and the 5-hydroxypentanoyltrifluoroborate $\left[\mathrm{C}_{5} \mathrm{H}_{9} \mathrm{BF}_{3} \mathrm{O}_{2}\right]^{-}$anion with the number of water molecules in the gas phase and aqueous solution by using the B3LYP/6-311++G** level of theory.

As a consequence of the hydration, these changes observed in the salt and its anion are in agreement with the variations previously observed in the bonds C9-O14, C2=O16, O14-H15 and K21-O16 lengths of this salt in solution [9]. Evidently, these sites are involved in the $\mathrm{H}$ bond formation due to the water molecules.

\subsection{Frontier orbitals and global descriptors studies.}

Here, the gap values for the salt and its anion were computed previously [9]. In this work, the values of different proposed clusters were calculated to see how the reactivities change when the number of water molecules increases from 1 to 5 . Hence, the differences between the two frontier orbitals, that are the gap values according to Parr and Pearson [31], together with the descriptors global electrophilicity $(\omega)$ and nucleophilicity $(E)$ indexes were also calculated to know the behaviors of these parameters with the different hydrations [3236,39-45]. Therefore, the results for the anion and the different clusters by using the B3LYP/6$311++\mathrm{G}^{* *}$ level of theory can be seen in Table 3. Analyzing the behaviors of gap values from Figure S1, it is observed that in the gas phase, the cluster with two water molecules presents the lower value, while in solution, the values for the anion and the five clusters are practically constant. If now the values of global electrophilicity indexes in the gas phase are analyzed from Figure S2, the values for the five clusters remain practically constant while in solution, the values increase with the number of water molecules presenting the higher value the cluster with 5 water molecules.

Table 3. Frontier orbitals and global electrophilicity $(\omega)$ and nucleophilicity $(E)$ index descriptors for the $\left[\mathrm{C}_{5} \mathrm{H}_{9} \mathrm{BF}_{3} \mathrm{O}_{2}\right] .\left[\mathrm{H}_{2} \mathrm{O}\right]_{\mathrm{n}}$ clusters of 5-hydroxypentanoyltrifluoroborate $\left[\mathrm{C}_{5} \mathrm{H}_{9} \mathrm{BF}_{3} \mathrm{O}_{2}\right]^{-}$anion in the gas phase and aqueous solution using the B3LYP/6-311++ $\mathrm{G}^{* *}$ level of theory.

\begin{tabular}{|c|c|c|c|c|c|}
\hline \multirow{3}{*}{ Species } & \multicolumn{5}{|c|}{ B3LYP/6-311++G** method ${ }^{\mathrm{a}}$} \\
\hline & \multicolumn{5}{|c|}{ Gas-phase } \\
\hline & HOMO & LUMO & GAP & $\omega$ & $\mathbf{E}$ \\
\hline$\left[\mathrm{C}_{5} \mathrm{H}_{9} \mathrm{BF}_{3} \mathrm{O}_{2}\right]^{-}$ & -1.9336 & 1.7576 & 3.6911 & 0.0021 & -0.1620 \\
\hline$\left[\mathrm{C}_{5} \mathrm{H}_{9} \mathrm{BF}_{3} \mathrm{O}_{2}\right]\left[\mathrm{H}_{2} \mathrm{O}\right]$ & -2.1180 & 1.3302 & 3.4482 & 0.0450 & -0.6790 \\
\hline$\left[\mathrm{C}_{5} \mathrm{H}_{9} \mathrm{BF}_{3} \mathrm{O}_{2}\right]\left[\mathrm{H}_{2} \mathrm{O}\right]_{2}$ & -2.1669 & 0.8257 & 2.9926 & 0.1503 & -1.0030 \\
\hline
\end{tabular}




\begin{tabular}{|c|c|c|c|c|c|}
\hline \multirow{3}{*}{ Species } & \multicolumn{5}{|c|}{ B3LYP/6-311++G** method $^{\mathrm{a}}$} \\
\hline & \multicolumn{5}{|c|}{ Gas-phase } \\
\hline & HOMO & LUMO & GAP & $\omega$ & $\mathbf{E}$ \\
\hline$\left[\mathrm{C}_{5} \mathrm{H}_{9} \mathrm{BF}_{3} \mathrm{O}_{2}\right]\left[\mathrm{H}_{2} \mathrm{O}\right]_{3}$ & -3.0057 & 1.9882 & 4.9940 & 0.0518 & -1.270 \\
\hline$\left[\mathrm{C}_{5} \mathrm{H}_{9} \mathrm{BF}_{3} \mathrm{O}_{2}\right]\left[\mathrm{H}_{2} \mathrm{O}\right]_{4}$ & -3.3543 & 1.8294 & 5.1837 & 0.1122 & -1.976 \\
\hline$\left[\mathrm{C}_{5} \mathrm{H}_{9} \mathrm{BF}_{3} \mathrm{O}_{2}\right]\left[\mathrm{H}_{2} \mathrm{O}\right]_{5}$ & -3.4578 & 1.8461 & 5.3039 & 0.1224 & -2.137 \\
\hline \multicolumn{6}{|c|}{$\begin{array}{c}\text { Aqueous Solution } \\
\end{array}$} \\
\hline & HOMO & LUMO & $\mid$ GAP & $\omega$ & $\mathrm{E}$ \\
\hline$\left[\mathrm{C}_{5} \mathrm{H}_{9} \mathrm{BF}_{3} \mathrm{O}_{2}\right]^{-}$ & -6.0366 & -0.5197 & 5.5170 & 1.9478 & -9.0430 \\
\hline$\left[\mathrm{C}_{5} \mathrm{H}_{9} \mathrm{BF}_{3} \mathrm{O}_{2}\right]\left[\mathrm{H}_{2} \mathrm{O}\right]$ & -6.0641 & -0.5444 & 5.5198 & 1.9780 & -9.1190 \\
\hline$\left[\mathrm{C}_{5} \mathrm{H}_{9} \mathrm{BF}_{3} \mathrm{O}_{2}\right]\left[\mathrm{H}_{2} \mathrm{O}\right]_{2}$ & -6.0382 & -0.6112 & 5.4270 & 2.0368 & -9.0220 \\
\hline$\left[\mathrm{C}_{5} \mathrm{H}_{9} \mathrm{BF}_{3} \mathrm{O}_{2}\right]\left[\mathrm{H}_{2} \mathrm{O}\right]_{3}$ & 6.2982 & -0.8507 & 5.4474 & 2.3454 & -9.7361 \\
\hline$\left[\mathrm{C}_{5} \mathrm{H}_{9} \mathrm{BF}_{3} \mathrm{O}_{2}\right]\left[\mathrm{H}_{2} \mathrm{O}\right]_{4}$ & -6.3651 & -0.9902 & 5.3750 & 2.5163 & -9.8843 \\
\hline$\left[\mathrm{C}_{5} \mathrm{H}_{9} \mathrm{BF}_{3} \mathrm{O}_{2}\right]\left[\mathrm{H}_{2} \mathrm{O}\right]_{5}$ & -6.4476 & -1.0357 & 5.4119 & 2.5869 & -10.1250 \\
\hline
\end{tabular}

In relation to the global nucleophilicity indexes, the behaviors for the five clusters in both media are approximately the same, however, the values are most negative in solution, increasing the value slightly from the cluster with 1 water molecule up to the most negative value for the cluster with 5 water molecules. Hence, the cluster with five water molecules presents the higher electrophilicity and most negative value of nucleophilicity, while the reactivity remains practically constant for all the clusters.

\subsection{Raman spectrum in aqueous solution.}

Previous work on this salt using B3LYP/6-311++G** calculations s optimized this salt's structures in the gas phase and aqueous solution with $\mathrm{C} 1$ symmetries, 57 and 54, the normal vibration modes expected for this salt and its anion, respectively [9]. All vibration modes of both species present activities in the infrared and Raman spectra.

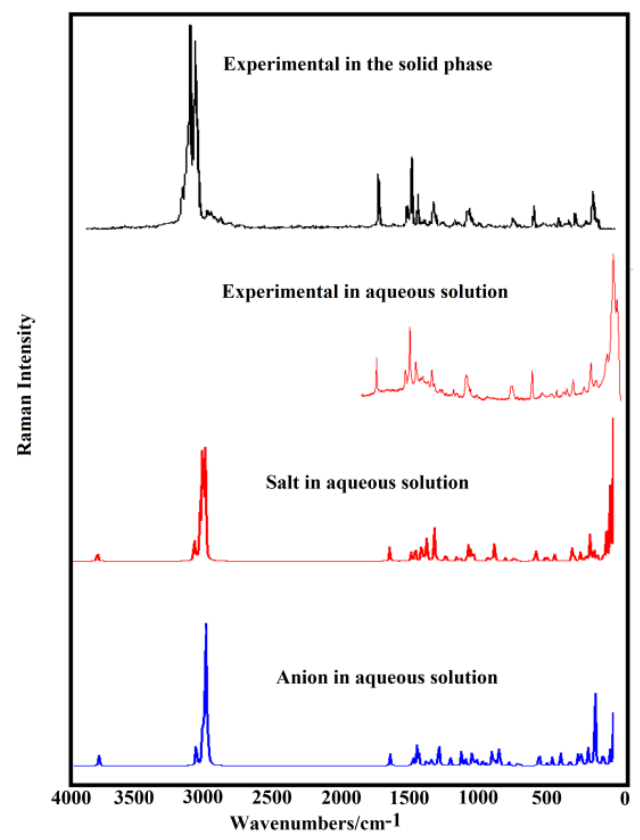

Figure 6. Experimental Raman of salt in the solidstate compared with the corresponding predicted solution for the salt and its anion in aqueous solution by using B3LYP/6-311++G** level of theory.

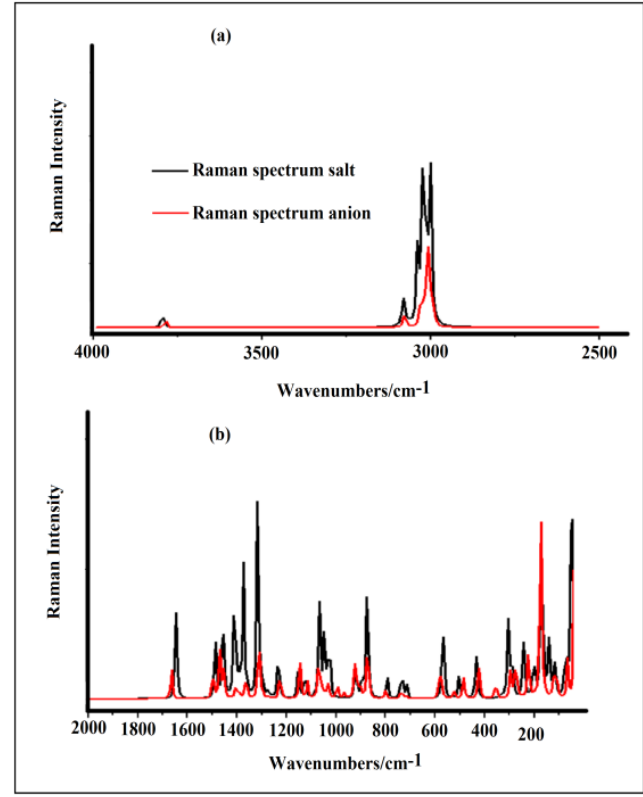

Figure 7. Predicted Raman of the salt and its anion by using B3LYP/6-311++G** level of theory in the $4000-2500 \mathrm{~cm}^{-1}$ (upper) and 2000-40 $\mathrm{cm}^{-1}$ (bottom) regions. 
The experimental Raman spectrum of the salt in the solid phase is compared with the corresponding recorded in this work in solution and with the predicted for the salt and its anion in Figure 6, while in Figure 7 are presented only the predicted Raman spectra in intensities for the salt and its anion by using B3LYP/6-311++G**level of theory. Note that the experimental Raman spectrum of salt in aqueous solution was possible to record only between 2000 and 40 $\mathrm{cm}^{-1}$ region.

The comparisons among the experimental and predicted Raman spectra show that in solution, the positions of bands in the salt and its anion practically do not change. Only a few bands are shifted in solution while being observed some strong changes in the intensities of many bands, as can be seen in Figures 6 and 7. In the predicted Raman spectra of salt in the $4000-2500 \mathrm{~cm}^{-1}$ region, four bands perfectly defined around $3000 \mathrm{~cm}^{-1}$. In the anion, only two bands with a shoulder with lower intensities are observed. In the $2000-40 \mathrm{~cm}^{-1}$ region are clearly observed the decrease in the intensities of bands attributed to the anion, as compared with the salt, but an increase in intensities of Raman bands located at 1150, 926 and $172 \mathrm{~cm}^{-1}$ are also observed. For instance, it is possible to observe a decrease notably in the intensities of two Raman bands of salt from 1417 and $1372 \mathrm{~cm}^{-1}$ to 1417 and $1361 \mathrm{~cm}^{-1}$ in the anion and, besides, the bands at $1321 \mathrm{~cm}^{-1}$ in the salt are shifted at $1300 \mathrm{~cm}^{-1}$ in the anion while appear two new bands at 1037 and $966 \mathrm{~cm}^{-1}$. Obviously, the shifting of some Raman bands toward lower wavenumbers is due to the hydration of involved $\mathrm{OH}, \mathrm{BF}_{3}$ and $\mathrm{C}=\mathrm{O}$ groups by water molecules. The assignments of both salt and anion in solution were previously performed with the harmonic force fields by using the SQMFF methodology, the normal internal coordinates and the Molvib program $[9,25,26]$. In Table 4 , the experimental and calculated wavenumbers are presented for the salt and its anion together with their complete assignments by using the B3LYP/6-311++ $\mathrm{G}^{* *}$ method. Figure S3 and S4 show the predicted infrared and Raman spectra for the five proposed clusters. Both figures show clearly the shifting and changes in the intensities of some bands and, in particular, the decrease in the intensities of bands observed between 200 and $40 \mathrm{~cm}^{-1}$. In the infrared spectra of all clusters are observed the increase in the intensities of bands between 4000 and $2500 \mathrm{~cm}^{-1}$. Then, the assignments of the most important groups are discussed briefly below.

\subsubsection{Band assignments.}

\subsubsection{OH modes.}

The vibration $\mathrm{OH}$ stretching modes in the anion and salt in the aqueous solution phase are predicted by SQM calculations at 3636 and $3634 \mathrm{~cm}^{-1}$, respectively. These modes were not assigned because the Raman spectrum was recorded between 2000 and $40 \mathrm{~cm}^{-1}$. The SQM calculations predicted the in-plane deformation or rocking modes of anion and salt in solution at 1309 and $1062 \mathrm{~cm}^{-1}$, as expected due to the hydration. Here, this strong shifting reveals the notable hydration of this group in solution. The corresponding out-of-plane deformation or torsion modes of this group in the anion and salt are predicted at 254 and $243 \mathrm{~cm}^{-1}$, evidencing clearly its hydration in solution by decreasing the band's intensity at $245 \mathrm{~cm}^{-1}$ attributed to this group. Obviously, the vibration modes related to $\mathrm{OH}$ group in the anion are shifted due to the hydration with the water molecules. 


\subsubsection{2. $\mathrm{BF}_{3}$ modes.}

SQM calculations predict the expected two anti-symmetric stretching modes for the salt and its anion in different positions, while the symmetric modes are predicted in approximately the same regions. This way, the Raman bands in solution located at $932 \mathrm{~cm}^{-1}$ are assigned to symmetric modes of anion while the band at $570 \mathrm{~cm}^{-1}$ can be assigned to the corresponding symmetric modes, as observed in Table 4.

The shifting observed for the anti-symmetric modes is clear evidence of the hydration of these groups in an aqueous solution. In the same way, the deformations, rocking and twisting modes in both species are slightly shifted in solution.

Table 4. Observed and calculated wavenumbers $\left(\mathrm{cm}^{-1}\right)$ and assignment for the $\left.\mathrm{K}_{2} \mathrm{C}_{5} \mathrm{H}_{9} \mathrm{BF}_{3} \mathrm{O}_{2}\right]$ salt and its 5hydroxypentanoyltrifluoroborate $\left[\mathrm{C}_{5} \mathrm{H}_{9} \mathrm{BF}_{3} \mathrm{O}_{2}\right]^{-}$anion in aqueous solution by using B3lyp/6-311++G** level of theory.

\begin{tabular}{|c|c|c|c|c|c|c|c|c|}
\hline \multirow{2}{*}{\multicolumn{3}{|c|}{ Experimental }} & \multicolumn{6}{|c|}{ B3LYP 6-311++G**b } \\
\hline & & & \multirow{2}{*}{\multicolumn{3}{|c|}{$\frac{\left[\mathrm{C}_{5} \mathrm{H}_{9} \mathrm{BF}_{3} \mathrm{O}_{2}\right]^{-}}{\text {Aqueous solution }}$}} & \multirow{2}{*}{\multicolumn{3}{|c|}{$\begin{array}{c}\mathrm{K}\left[\mathrm{C}_{5} \mathrm{H}_{9} \mathrm{BF}_{3} \mathrm{O}_{2}\right] \\
\text { Aqueous solution }\end{array}$}} \\
\hline \multicolumn{2}{|c|}{ Solid phase $^{b}$} & \multirow{2}{*}{$\begin{array}{c}\text { Solution }^{\mathrm{a}} \\
\text { Raman }\end{array}$} & & & & & & \\
\hline \multirow[t]{2}{*}{ IR } & Raman & & Calc & SQM $^{\mathbf{c}}$ & Assignment $^{\text {b }}$ & Calc & SQM $^{\mathbf{c}}$ & Assignment $^{\mathbf{b}}$ \\
\hline & & & 3793 & 3636 & $v \mathrm{O}-\mathrm{H}$ & 3791 & 3634 & $v \mathrm{O}-\mathrm{H}$ \\
\hline $2962 \mathrm{~m}$ & & & 3082 & 2954 & $\mathrm{vaCH}_{2}(\mathrm{C} 9)$ & 3087 & 2950 & $\mathrm{vaCH}_{2}(\mathrm{C} 9)$ \\
\hline $2944 \mathrm{~m}$ & & & 3065 & 2939 & $v_{\mathrm{a}} \mathrm{CH}_{2}(\mathrm{C} 5)$ & 3063 & 2926 & $v_{\mathrm{a}} \mathrm{CH}_{2}(\mathrm{C} 5)$ \\
\hline \multirow[t]{2}{*}{$2910 \mathrm{vs}$} & & & 3037 & 2912 & $v_{\mathrm{a}} \mathrm{CH}_{2}(\mathrm{C} 6)$ & 3041 & 2906 & $\mathrm{v}_{\mathrm{a}} \mathrm{CH}_{2}(\mathrm{C} 6)$ \\
\hline & & & 3028 & 2903 & $v_{\mathrm{a}} \mathrm{CH}_{2}(\mathrm{C} 1)$ & 3026 & 2891 & $v_{\mathrm{a}} \mathrm{CH}_{2}(\mathrm{C} 1)$ \\
\hline $2876 \mathrm{vs}$ & & & 3023 & 2898 & $v_{\mathrm{s}} \mathrm{CH}_{2}(\mathrm{C} 9)$ & 3024 & 2889 & $v_{\mathrm{s}} \mathrm{CH}_{2}(\mathrm{C} 5)$ \\
\hline 2876vs & & & 3022 & 2897 & $v_{\mathrm{s}} \mathrm{CH}_{2}(\mathrm{C} 9)$ & 3015 & 2881 & $v_{\mathrm{s}} \mathrm{CH}_{2}(\mathrm{C} 9$ \\
\hline $2876 \mathrm{vs}$ & & & 3004 & 2881 & $v_{\mathrm{s}} \mathrm{CH}_{2}(\mathrm{C} 1)$ & 3009 & 2875 & $v_{\mathrm{s}} \mathrm{CH}_{2}(\mathrm{C} 6)$ \\
\hline 2876vs & & & 3002 & 2878 & $v_{\mathrm{s}} \mathrm{CH}_{2}(\mathrm{C} 6)$ & 3005 & 2872 & $v_{\mathrm{s}} \mathrm{CH}_{2}(\mathrm{C} 1)$ \\
\hline $1665 \mathrm{~m}$ & $1670 \mathrm{~s}$ & $1671 \mathrm{~m}$ & 1654 & 1593 & $v \mathrm{C} 2=\mathrm{O} 16$ & 1655 & 1592 & $v \mathrm{C} 2=\mathrm{O} 16$ \\
\hline $1474 w$ & 1476 & $1477 \mathrm{w}$ & 1495 & 1430 & $\delta \mathrm{CH}_{2}(\mathrm{C} 9)$ & 1507 & 1441 & $\delta \mathrm{CH}_{2}(\mathrm{C} 9)$ \\
\hline $1445 \mathrm{~m}$ & $1448 \mathrm{vs}$ & $1488 \mathrm{~s}$ & 1483 & 1417 & $\delta \mathrm{CH}_{2}(\mathrm{C} 5)$ & 1487 & 1421 & $\delta \mathrm{CH}_{2}(\mathrm{C} 5)$ \\
\hline \multirow[t]{2}{*}{$1405 \mathrm{~m}$} & $1408 \mathrm{~s}$ & $1409 w$ & 1457 & 1394 & wagCH$_{2}(\mathrm{C} 9)$ & 1467 & 1402 & $\delta \mathrm{CH}_{2}(\mathrm{C} 6)$ \\
\hline & & $1402 \mathrm{sh}$ & 1421 & 1389 & wagCH $_{2}(\mathrm{C} 9)$ & 1419 & 1396 & wagCH$_{2}(\mathrm{C} 9)$ \\
\hline $1375 \mathrm{vw}$ & & 1379sh & 1417 & 1379 & wagCH$_{2}(\mathrm{C} 5)$ & 1417 & 1378 & $\mathrm{wagCH}_{2}(\mathrm{C} 5)$ \\
\hline \multirow[t]{2}{*}{$1361 \mathrm{vw}$} & $1362 w$ & $1361 \mathrm{w}$ & 1396 & 1360 & wagCH$_{2}(\mathrm{C} 6)$ & 1389 & 1346 & $\delta \mathrm{CH}_{2}(\mathrm{C} 1)$ \\
\hline & $1347 w$ & $1346 \mathrm{w}$ & 1372 & 1333 & $\delta \mathrm{CH}_{2}(\mathrm{C} 1)$ & 1372 & 1335 & $\rho \mathrm{CH}_{2}(\mathrm{C} 9)$ \\
\hline $1324 \mathrm{vw}$ & $1328 w$ & $1327 \mathrm{w}$ & 1361 & 1309 & $\rho \mathrm{CH}_{2}(\mathrm{C} 9)$ & 1345 & 1320 & wagCH$_{2}(\mathrm{C} 1)$ \\
\hline $1299 w$ & $1302 \mathrm{~m}$ & $1302 w$ & 1319 & 1285 & $\rho \mathrm{CH}_{2}$ (C5) & 1321 & 1304 & $\rho \mathrm{CH}_{2}(\mathrm{C} 6)$ \\
\hline $1284 \mathrm{w}$ & $1285 \mathrm{w}$ & $1286 \mathrm{w}$ & 1300 & 1260 & wagCH $_{2}(\mathrm{C} 5)$ & 1305 & 1284 & $\rho \mathrm{CH}_{2}(\mathrm{C} 5)$ \\
\hline \multirow[t]{2}{*}{$1245 \mathrm{vw}$} & $1246 \mathrm{w}$ & $1250 \mathrm{w}$ & 1277 & 1241 & $\rho \mathrm{CH}_{2}(\mathrm{C} 6)$ & 1270 & 1251 & wagCH $_{2}(\mathrm{C} 6)$ \\
\hline & $1232 w$ & $1233 w$ & & & & 1251 & 1229 & $\tau \mathrm{wCH}_{2}(\mathrm{C} 6)$ \\
\hline $1156 \mathrm{vw}$ & $1158 \mathrm{w}$ & $1159 w$ & 1235 & 1182 & $\rho \mathrm{CH}_{2}(\mathrm{C} 1)$ & & & \\
\hline $1134 \mathrm{vw}$ & $1137 \mathrm{w}$ & $1136 \mathrm{w}$ & 1150 & 1123 & $v \mathrm{C} 2-\mathrm{B} 17$ & 1156 & 1123 & $v \mathrm{C} 2-\mathrm{B} 17$ \\
\hline $1128 \mathrm{vw}$ & & & & & & 1134 & 1106 & $\rho \mathrm{CH}_{2}(\mathrm{C} 1)$ \\
\hline $1074 w$ & $1074 \mathrm{~m}$ & $1075 \mathrm{~m}$ & 1130 & 1095 & $\rho \mathrm{CH}_{2}(\mathrm{C} 6)$ & 1086 & 1062 & $\delta(\mathrm{O}-\mathrm{H})$ \\
\hline $1063 w$ & $1057 \mathrm{sh}$ & & 1077 & 1036 & vC5-C6 & 1064 & 1026 & $v \mathrm{C} 1-\mathrm{C} 5$ \\
\hline $1045 w$ & $1045 w$ & 1046sh & & & & 1046 & 1006 & vC5-C6 \\
\hline $1025 w$ & & & 1055 & 1034 & vC6-C9 & 1040 & 1001 & vC6-C9 \\
\hline 989vw & $1002 w$ & $1003 \mathrm{vw}$ & 1037 & 997 & $v \mathrm{C} 1-\mathrm{C} 5$ & & & \\
\hline $974 \mathrm{vw}$ & & & 966 & 978 & $\tau \mathrm{wCH} \mathrm{CH}_{2}(\mathrm{C} 5)$ & & & \\
\hline $921 \mathrm{vw}$ & $935 \mathrm{w}$ & $932 \mathrm{w}$ & 956 & 945 & $v_{\mathrm{a}} \mathrm{BF}_{3}$ & 991 & 960 & $v_{\mathrm{a}} \mathrm{BF}_{3}$ \\
\hline $921 \mathrm{vw}$ & $935 \mathrm{w}$ & $932 \mathrm{w}$ & 919 & 910 & $v_{\mathrm{a}} \mathrm{BF}_{3}$ & 983 & 950 & vC9-O14 \\
\hline \multirow[t]{2}{*}{$893 \mathrm{vw}$} & & & 906 & 890 & vC2-C1 & 969 & 937 & $v_{\mathrm{a}} \mathrm{BF}_{3}$ \\
\hline & & & 893 & 862 & vC9-O14 & 904 & 888 & $\tau \mathrm{wCH}_{2}(\mathrm{C} 9)$ \\
\hline $773 w$ & $775 \mathrm{~m}$ & $773 \mathrm{w}$ & 859 & 838 & $\tau \mathrm{wCH}_{2}(\mathrm{C} 9)$ & 885 & 855 & $v \mathrm{C} 2-\mathrm{C} 1$ \\
\hline $741 \mathrm{vw}$ & $769 \mathrm{~m}$ & & 813 & 757 & $\tau \mathrm{wCH} 2(\mathrm{C} 6)$ & 790 & 780 & $\tau \mathrm{wCH}_{2}(\mathrm{C} 1)$ \\
\hline $733 \mathrm{vw}$ & $734 w$ & $734 w$ & 751 & 732 & $\beta C 2=016$ & 766 & 743 & $\beta C 2=016$ \\
\hline $635 \mathrm{w}$ & $638 \mathrm{~s}$ & $638 \mathrm{~m}$ & 732 & 669 & $\tau \mathrm{wCH} 2(\mathrm{C} 5)$ & 740 & 731 & $\mathrm{wagCH}_{2}(\mathrm{C} 5)$ \\
\hline \multirow[t]{2}{*}{$556 \mathrm{vw}$} & $568 w$ & $570 \mathrm{w}$ & 605 & 593 & $v_{\mathrm{s}} \mathrm{BF}_{3}$ & 603 & 587 & $v_{\mathrm{s}} \mathrm{BF}_{3}$ \\
\hline & & & 548 & 521 & $\tau \mathrm{wCH}_{2}(\mathrm{C} 1)$ & 550 & 541 & $\gamma \mathrm{C} 2=\mathrm{O} 16$ \\
\hline $503 \mathrm{vw}$ & $509 w$ & $509 w$ & 526 & 513 & 8С6C9O14 & & & \\
\hline
\end{tabular}




\begin{tabular}{|c|c|c|c|c|c|c|c|c|}
\hline \multirow{2}{*}{\multicolumn{3}{|c|}{ Experimental }} & \multicolumn{6}{|c|}{ B3LYP 6-311++G**b } \\
\hline & & & \multirow{2}{*}{\multicolumn{3}{|c|}{$\begin{array}{c}{\left[\mathrm{C}_{5} \mathrm{H}_{9} \mathrm{BF}_{3} \mathrm{O}_{2}\right]^{-}} \\
\text {Aqueous solution }\end{array}$}} & \multirow{2}{*}{\multicolumn{3}{|c|}{$\begin{array}{c}\mathrm{K}\left[\mathrm{C}_{5} \mathrm{H}_{9} \mathrm{BF}_{3} \mathrm{O}_{2}\right] \\
\text { Aqueous solution }\end{array}$}} \\
\hline \multicolumn{2}{|c|}{ Solid phase $^{\mathrm{b}}$} & \multirow{2}{*}{$\begin{array}{c}\text { Solution } \\
\text { Raman }\end{array}$} & & & & & & \\
\hline IR & Raman & & Calc & SQM $^{\mathbf{c}}$ & Assignment $^{\mathrm{b}}$ & Calc & SQM $^{\mathrm{c}}$ & Assignment $^{b}$ \\
\hline \multirow{2}{*}{$470 \mathrm{w}$} & $473 w$ & $474 w$ & 469 & 462 & $\delta \mathrm{C} 6 \mathrm{C} 9014$ & 496 & 485 & $\delta_{\mathrm{a}} \mathrm{BF}_{3}$ \\
\hline & $427 \mathrm{w}$ & $428 w$ & & & & 465 & 446 & 8С6C9O14 \\
\hline $404 \mathrm{vw}$ & 406w & $403 w$ & 405 & 402 & $\delta_{\mathrm{a}} \mathrm{BF}_{3}$ & 400 & 397 & $\delta_{\mathrm{a}} \mathrm{BF}_{3}$ \\
\hline $383 \mathrm{vvw}$ & & & & & & 390 & 379 & $\delta \mathrm{C} 1 \mathrm{C} 5 \mathrm{C} 6$ \\
\hline \multirow[t]{2}{*}{$362 \mathrm{vvw}$} & $366 \mathrm{~m}$ & $367 \mathrm{w}$ & 359 & 356 & $\delta_{\mathrm{a}} \mathrm{BF}_{3}$ & 353 & 347 & $\delta_{\mathrm{s}} \mathrm{BF}_{3}$ \\
\hline & & & 345 & 339 & $v \mathrm{C} 2-$ & & & \\
\hline $288 \mathrm{vw}$ & $291 w$ & $291 w$ & 318 & 309 & $8 \mathrm{C} 5 \mathrm{C} 6 \mathrm{C} 9$ & 296 & 285 & $\rho^{\prime} \mathrm{BF}_{3}$ \\
\hline $244 \mathrm{~m}$ & $246 \mathrm{~s}$ & $245 \mathrm{w}$ & 278 & 254 & $\tau \mathrm{O}-\mathrm{H}$ & 264 & 243 & $\tau \mathrm{O}-\mathrm{H}$ \\
\hline $221 \mathrm{vvw}$ & & & 253 & 247 & $8 \mathrm{C} 1 \mathrm{C} 5 \mathrm{C} 6$ & 230 & 218 & $\delta \mathrm{C} 2 \mathrm{C} 1 \mathrm{C} 5$ \\
\hline $213 \mathrm{vw}$ & $213 w$ & $213 w$ & 201 & 192 & $\rho^{\prime} \mathrm{BF}_{3}$ & 197 & 193 & $\rho \mathrm{BF}_{3}$ \\
\hline $180 \mathrm{vvw}$ & $183 \mathrm{sh}$ & & 188 & 183 & $\rho \mathrm{BF}_{3}$ & 167 & 162 & $v \mathrm{~F} 20-\mathrm{K} 21$ \\
\hline $160 \mathrm{vvw}$ & 158sh & & & & & 157 & 150 & $8 \mathrm{C} 5 \mathrm{C} 6 \mathrm{C} 9$ \\
\hline $135 \mathrm{vvw}$ & $139 \mathrm{~s}$ & $139 \mathrm{~m}$ & 138 & 128 & $\tau \mathrm{C} 9-\mathrm{C} 6$ & 149 & 135 & $\tau \mathrm{C} 9-\mathrm{C} 6$ \\
\hline $127 \mathrm{vvw}$ & & & & & & 127 & 115 & $\tau \mathrm{C} 5-\mathrm{C} 6$ \\
\hline \multirow[t]{6}{*}{$113 \mathrm{vvw}$} & 96vs & $97 \mathrm{vs}$ & 108 & 98 & $\tau \mathrm{C} 5-\mathrm{C} 6$ & 74 & 69 & $\tau \mathrm{C} 1-\mathrm{C} 5$ \\
\hline & $71 \mathrm{~s}$ & $72 \mathrm{~s}$ & 90 & 84 & $8 \mathrm{C} 1 \mathrm{C} 2 \mathrm{~B} 17$ & 60 & 56 & $\tau \mathrm{C} 1-\mathrm{C} 2$ \\
\hline & & & 63 & 54 & $\tau \mathrm{C} 1-\mathrm{C} 5$ & 52 & 51 & $\delta \mathrm{C} 1 \mathrm{C} 2 \mathrm{~B} 17$ \\
\hline & & & & & & 50 & 47 & $v \mathrm{~F} 18-\mathrm{K} 21$ \\
\hline & & & 47 & 28 & $\tau \mathrm{C} 1-\mathrm{C} 2$ & 31 & 30 & $\tau \mathrm{wBF}_{3}$ \\
\hline & & & 18 & 17 & $\tau \mathrm{wBF}_{3}$ & 6 & 6 & $\delta \mathrm{K} 21 \mathrm{~B} 17 \mathrm{C} 2$ \\
\hline
\end{tabular}

Abbreviations: $v$, stretching; $\beta$, deformation in the plane; $\gamma$, deformation out of a plane; wag, wagging; $\tau$, torsion; $\beta_{\mathrm{R}}$, deformation ring $\tau_{\mathrm{R}}$, torsion ring; $\rho$, rocking; $\tau_{\mathrm{w}}$, twisting; $\delta$, deformation; a, anti-symmetric; s, symmetric, ${ }^{\text {a }}$ This work, ${ }^{b}$ From Ref [9], ${ }^{c}$ From scaled quantum mechanics force field.

\subsubsection{3. $\mathrm{CH}_{2}$ modes.}

Previously, the anti-symmetric and symmetric stretching modes were assigned to the IR and Raman bands between 2962 and $2866 \mathrm{~cm}^{-1}$. Here, we can observe differences in the salt's assignments in solution compared with the corresponding to anion. Hence, the SQM calculations predicted those two stretching modes in the salt and its anion in different regions. These modes were not assigned because the Raman spectrum of salt in solution was recorded between 2000 and $40 \mathrm{~cm}^{-1}$. The $\mathrm{CH}_{2}$ deformation, waging, rocking, and twisting modes are predicted at 1441/1389, 1394/1123, 1304/1095 and 978/669 $\mathrm{cm}^{-1}$. Hence, these vibration modes can be assigned in those regions, as observed in Table 4.

\subsubsection{Skeletal modes.}

In the previous study on the salt, the strong IR band at $1667 \mathrm{~cm}^{-1}$ was assigned to the $\mathrm{C}=\mathrm{O}$ stretching modes. In solution, those modes were predicted in the same region for the salt and its anion, for which these modes can be attributed to the Raman band at $1671 \mathrm{~cm}^{-1}$. Here, the hydration effect is evidenced by the decrease in the intensity of the Raman band in the solid phase of the salt, as compared with the Raman spectrum in solution. On the other side, the C2B17 stretching mode that contains the $\mathrm{CF}_{3}$ group is predicted in the salt in solution in the same position as the anion at $1123 \mathrm{~cm}^{-1}$, for this reason, this mode is associated with the Raman band at $1136 \mathrm{~cm}^{-1}$. On the other side, the $\mathrm{C} 9-\mathrm{O} 14$ stretching modes belong to the $\mathrm{OH}$ group are predicted at $950 \mathrm{~cm}^{-1}$ in the salt and at $862 \mathrm{~cm}^{-1}$ in the anion. Hence, these vibration modes are also influenced by hydration. Therefore, those vibration modes can be assigned in the regions predicted by calculations. The other vibration modes were assigned in accordance with the SQM calculations, as detailed in Table 4. The Raman spectra in solution evidence the presence of anion in aqueous solution and, in addition, show clearly that the hydration regions are related to the $\mathrm{OH}, \mathrm{BF}_{3}$ and $\mathrm{C}=\mathrm{O}$ groups. 


\subsection{Ultraviolet-visible spectrum}

The experimental electronic spectrum of the salt in an aqueous solution was presented in the previous article in the $200-400 \mathrm{~nm}$ region [9] while, in this work, the experimental UVvisible spectrum was newly recorded between 182 and $400 \mathrm{~nm}$ region. Hence, Figure 8 presents the experimental spectrum in aqueous solution compared with the predicted for the salt and its anion in the same medium by using TD-DFT calculations, the B3LYP/6-311++G** method the Gaussian program [29].

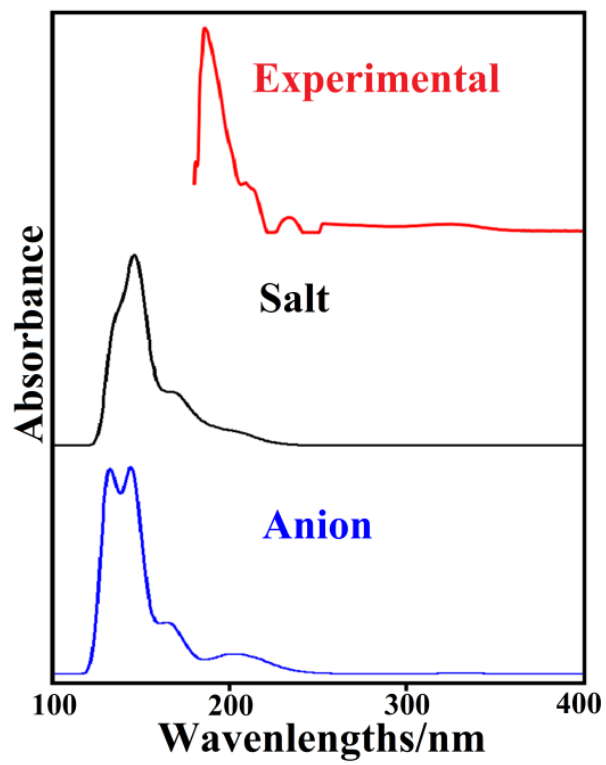

Figure 8. Experimental UV-visible spectrum of salt in aqueous solution compared with those predicted for the salt and its anion by using B3LYP/6-311++G** level of theory.

On the other hand, Figure S5 can be seen as the predicted ultraviolet-visible spectra for the $\left[\mathrm{C}_{5} \mathrm{H}_{9} \mathrm{BF}_{3} \mathrm{O}_{2}\right] .\left[\mathrm{H}_{2} \mathrm{O}\right]_{n}$ clusters of anion, with $\mathrm{n}$ from 1 to 5 water molecules, compared with the corresponding experimental of salt in aqueous solution. Obviously, in aqueous solution is expected the anionic species, as was also reported for IFTB [8]. In this new experimental spectrum presented of salt in an aqueous solution, it is possible to see that the strong band observed at $188.5 \mathrm{~nm}$ agrees with those predicted by all clusters between 150 and $200 \mathrm{~nm}$. These results show that 1 or 5 water molecules cannot hydrate the salt because their UV-vis spectra present only a band between 180 and $200 \mathrm{~nm}$, different from the experimental spectra where are observed a band and a shoulder in that region. Table 5 are summarized the positions of bands observed and calculated for the $\mathrm{K}_{2}\left[\mathrm{C}_{5} \mathrm{H}_{9} \mathrm{BF}_{3} \mathrm{O}_{2}\right]$ salt and its 5hydroxypentanoyltrifluoroborate $\left[\mathrm{C}_{5} \mathrm{H}_{9} \mathrm{BF}_{3} \mathrm{O}_{2}\right]^{-}$anion in an aqueous solution by using the B31yp/6-311++G** level of theory.

Table 5. TD-DFT calculated visible absorption wavelengths (nm) for the $\mathrm{K}\left[\mathrm{C}_{5} \mathrm{H}_{9} \mathrm{BF}_{3} \mathrm{O}_{2}\right]$ salt and its 5hydroxypentanoyltrifluoroborate $\left[\mathrm{C}_{5} \mathrm{H}_{9} \mathrm{BF}_{3} \mathrm{O}_{2}\right]^{-}$anion in aqueous solution by using B3lyp/6-311++G** level of theory compared with the corresponding experimental for the salt in aqueous solution.

\begin{tabular}{c|c|c|c}
\hline \multirow{2}{*}{ Experimental $^{\mathbf{a}}$} & \multicolumn{3}{|c}{ B3lyp/6-311++G** method } \\
\cline { 2 - 4 } & Anion & Salt & Assignment $^{\mathbf{b}}$ \\
\hline $188.5 \mathrm{vs}$ & $144.7 \mathrm{vs}$ & $140.7 \mathrm{vs}$ & $\mathrm{n} \rightarrow \sigma^{*}$ \\
\hline $211.5 \mathrm{sh}$ & $132.9 \mathrm{vs}$ & $135.8 \mathrm{sh}$ & $\mathrm{n} \rightarrow \sigma^{*}$ \\
\hline $236.5 \mathrm{w}$ & $166.9 \mathrm{~m}$ & $169.2 \mathrm{~m}$ & $\mathrm{n} \rightarrow \sigma^{*}$ \\
\hline $325.0 \mathrm{vw}$ & $204.1 \mathrm{w}$ & $206.8 \mathrm{sh}$ & $\mathrm{n} \rightarrow \sigma^{*}$ \\
\hline
\end{tabular}

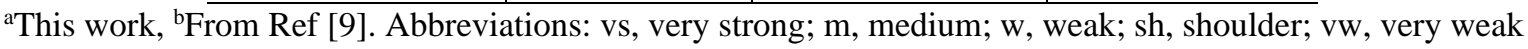


Experimentally, intense bands at c.a. $188.5 \mathrm{~nm}$ and a weak band at $325 \mathrm{~nm}$ are observed. In the predicted spectrum for salt, a strong band at $140.7 \mathrm{~nm}$ and two shoulders at 135.8 and $206.8 \mathrm{~nm}$ are observed and other bands of medium intensity at $169.2 \mathrm{~nm}$. Two strong bands are predicted at 144.7 and $132.9 \mathrm{~nm}$ in the anion and the other two bands at 166.9 and 204.1 $\mathrm{nm}$. These bands are assigned easily to $\mathrm{n} \rightarrow \sigma^{*}$ transitions from the lone pairs of $\mathrm{O}$ and $\mathrm{F}$ atoms belong to the $\mathrm{C}=\mathrm{O}$ and $\mathrm{BF}_{3}$ groups toward different anti-bonding $\mathrm{C}-\mathrm{C}, \mathrm{C}-\mathrm{B}$ and $\mathrm{B}-\mathrm{F}$ orbitals due to the presence of the side chain, as suggested by the NBO analysis performed from previous studies [9]. In other trifluoroborate salts in aqueous solution are observed $n \rightarrow \pi^{*}$ transitions due to the presence of $\mathrm{C}=\mathrm{C}$ bonds of pyridine and furoyl rings $[7,8,10]$.

\section{Conclusions}

In this work, the hydration of potassium 5-hydroxypentanoyltrifluoroborate salt, $\mathrm{K}\left[\mathrm{C}_{5} \mathrm{H}_{9} \mathrm{BF}_{3} \mathrm{O}_{2}\right]$ and its 5-hydroxypentanoyltrifluoroborate $\left[\mathrm{C}_{5} \mathrm{H}_{9} \mathrm{BF}_{3} \mathrm{O}_{2}\right]^{-}$anion have been studied by combining the experimental FT-Raman and ultraviolet-visible spectra in aqueous solution with hybrid B3LYP/6-311++G** calculations. The calculations were performed in the gas phase and an aqueous solution to observe the changes in the energy, dipole moment and volume values. The solvent effects were considered with the SCRF and SM models. Here, the structures of $\left[\mathrm{C}_{5} \mathrm{H}_{9} \mathrm{BF}_{3} \mathrm{O}_{2}\right] .\left[\mathrm{H}_{2} \mathrm{O}\right]_{\mathrm{n}}$ clusters of anion, with $\mathrm{n}$ implicit water molecules, from 1 to 5 , were proposed to study the number of water molecules that could hydrate the anion. The calculated solvation energies for all clusters were corrected by ZPVE, non-electrostatic terms and by BSSE. The dipole moment of salt in solution (10.19 D) suggests that the number of water molecules that could hydrate the anion vary between 3 and 4, in total agreement with the two observed and predicted bands in the UV-Vis spectra for the clusters with 3 or 4 water molecules and the salt in water between 180 and $200 \mathrm{~nm}$. On the other hand, the comparisons among the experimental and predicted Raman spectra show clearly the hydration effect because the bands attributed to $\mathrm{OH}, \mathrm{BF}_{3}$ and $\mathrm{C}=\mathrm{O}$ groups are shifted in solution while the predicted Raman spectra for all clusters in solution show strong changes in the intensities of many bands, in accordance with the corresponding experimental one. Evidently, the hydration occurs on the $\mathrm{OH}, \mathrm{BF}_{3}$ and $\mathrm{C}=\mathrm{O}$ groups. The frontier orbitals studies have revealed that in solution, the reactivities of anion and the five clusters remain practically constant, while the global electrophilicity indexes increase with the number of water molecules having the global nucleophilicity indexes all clusters in solution the most negative values.

\section{Supporting Information Available}

Figures S1-S5.

\section{Funding}

This research received no external funding.

\section{Acknowledgments}

This work was supported with grants from CIUNT Project $N^{\circ}$ 26/D608 (Consejo de Investigaciones, Universidad Nacional de Tucumán, Argentina). The authors would like to thank Prof. Tom Sundius for his permission to use MOLVIB. 


\section{Conflicts of Interest}

The authors declare no conflict of interest.

\section{References}

1. Bichara, L.C.; Brandán, S.A. Hydration of species derived from ascorbic acid in aqueous solution. An experimental and theoretical study by using DFT calculations. J. Mol. Liq. 2013, 181, 34-43, http://dx.doi.org/10.1016/j.molliq.2013.02.009.

2. Romano, E.; Castillo, M.V.; Márquez, M.B.; Gramajo, M.B.; Brandán, S.A. Physicochemical properties of the antihypertensive agent 2-benzylimidazoline in aqueous and physiological solutions at 25 and $37{ }^{\circ} \mathrm{C} . J$. Mol. Liq. 2014, 196, 285-290, http://dx.doi.org/10.1016/j.molliq.2014.03.036.

3. Bichara, L.C.; Lanús, H.E.; Brandán, S.A. Stabilities of aqueous solutions of sucrose containing ascorbic and citric acids by using FTIR spectroscopy and physicochemical studies. J. Mol. Liq. 2014, 200, 448-459, http://dx.doi.org/10.1016/j.molliq.2014.10.038.

4. Falcicchio, A.; Lill, S.O.N.; Perna, F.M.; Salomone, A.; Coppi, D.I.; Cuocci, C.; Stalked, D.; Capriati, V. Organotrifluoroborates as attractive self-assembling systems: the case of bifunctional dipotassium phenylene1,4-bis(trifluoroborate). Dalton Trans. 2015, 44, 19447-19450, https://doi.org/10.1039/c5dt02020d.

5. Kamiński, R.; Jarzembska, K.N.; Dąbrowski, M.; Durka, K.; Kubsik, M.; Serwatowski, J.; Woźniak, K. Finding Rules Governing Layered Architectures of Trifluoroborate Potassium Salts in the Solid State. Cryst. Growth Des. 2016, 16, 1687-1700, https://doi.org/10.1021/acs.cgd.5b01760.

6. Bateman, C.M.; Zakharov, L.N.; Abbey, E.R. Crystal structure of triphenylphosphoniummethylenetrifluoroborate. Acta Cryst. 2017, E73, 1140-1142, https://doi.org/10.1107/s2056989017009884.

7. Iramain, M.A.; Davies, L.; Brandán, S.A. FTIR, FT-Raman and UV-visible spectra of Potassium 3furoyltrifluoroborate. J. Mol. Struct. 2018, 1158, 245-254, https://doi.org/10.1016/j.molstruc.2018.01.040.

8. Iramain, M.A.; Davies, L.; Brandán, S.A. Evaluating structures, properties and vibrational and electronic spectra of the potassium 2-isonicotinoyltrifluoroborate salt. J. Mol. Struct. 2018, 1163, 41-53, https://doi.org/10.1016/j.molstruc.2018.02.098.

9. Iramain, M.A.; Davies, L.; Brandán, S.A. Structural and spectroscopic differences among the potassium 5hydroxypentanoyltrifluoroborate salt and the furoyl and isonicotinoyl salts. J. Mol. Struct. 2019, 1176, 718728, https://doi.org/10.1016/j.molstruc.2018.09.015.

10. Iramain, M.A.; Ledesma, A.E.; Brandán, S.A. Structural properties and vibrational analysis of Potassium 5$\mathrm{Br}-2$-isonicotinoyltrifluoroborate salt. Effect of $\mathrm{Br}$ on the isonicotinoyl ring. J Mol. Struct. 2019, 1184, 146156, https://doi.org/10.1016/j.molstruc.2019.02.010.

11. Iramain, M.A.; Brandán, S.A. Impact of $\mathrm{Br}$ on the isonicotinoyl ring and its effects on the properties of Potassium 5-Br-2-isonicotinoyltrifluoroborate salt in different media. J. Mol. Modeling 2018, 25, 348, https://doi.org/10.1007/s00894-019-4234-x.

12. Pusterla, I.; Bode, J.W. The mechanism of the $\alpha$-ketoacid-Hydroxylamine Amide-Forming Ligation. Angew. Chem. 2012, 51, 513-516, https://doi.org/10.1002/anie.201107198.

13. Schuhmacher A.; Ryan S.J.; Bode J.W., Catalytic Synthesis of Potassium Acyltrifluoroborates (KATs) from Boronic Acids and the Thioimidate KAT Transfer Reagent, Angewandte chemie, 2021, 60 (8), 3918-3922. https://doi.org/10.1002/anie.202014581

14. Schauenburg D.; Divandari M.; Neumann K.; Spiegel C. A.; Hackett T.; Dzeng Y.; Spencer N. D.; Bode J.W., Synthesis of Polymers Containing Potassium Acyltrifluoroborates (KATs) and Post-polymerization Ligation and Conjugation, Angewandte chemie, 2020, 59 (34), 14656-14663. https://doi.org/10.1002/anie.202006273

15. Schuhmacher, A.; Shiro, T.; Sarah J. R.; Bode, J. W., Synthesis of secondary and tertiary amides without coupling agents from amines and potassium acyltrifluoroborates (KATs), Chem. Sci. 2020, 11, 7609-7614. https://doi.org/10.1039/D0SC01330G

16. Noda, H.; Erős, G.; Bode, J.W. Rapid Ligations with Equimolar Reactants in Water with the Potassium Acyltrifluoroborate (KAT) Amide Formation. J. Am. Chem. Soc. 2014, 136, 5611-5614, https://doi.org/10.1021/ja5018442. 
17. Noda, H.; Bode, J.W. Synthesis of Chemically and Configurationally Stable Monofluoro Acylboronates: Effect of Ligand Structure on their Formation, Properties, and Reactivities. J. Am. Chem. Soc. 2015, 137, 3958-3966, https://doi.org/10.1021/jacs.5b00822.

18. Noda, H.; Bode, J.W. Synthesis and Reactivities of Monofluoro Acylboronates in Chemoselective Amide Bond Forming Ligation with Hydroxylamines. Org Biomol Chem. 2016, 14, 16-20, https://doi.org/10.1039/c5ob02118a.

19. Becke, A.D. Density-functional exchange-energy approximation with correct asymptotic behavior. Phys. Rev. 1988, A38, 3098-3100, https://doi.org/10.1103/PhysRevA.38.3098.

20. Lee, C.; Yang, W.; Parr, R.G. Development of the Colle-Salvetti correlation-energy formula into a functional of the electron density. Phys. Rev. 1988, B37, 785-789, https://doi.org/10.1103/PhysRevB.37.785.

21. Miertus, S.; Scrocco, E.; Tomasi, J. Electrostatic interaction of a solute with a continuum. A direct utilization of $\mathrm{AB}$ initio molecular potentials for the prevision of solvent effects. Chem. Phys. 1981, 55, 117-129, https://doi.org/10.1016/0301-0104(81)85090-2.

22. Tomasi, J.; Persico, J. Molecular Interactions in Solution: An Overview of Methods Based on Continous Distributions of the Solvent. Chem. Rev. 1994, 94, 2027-2094, https://doi.org/10.1021/cr00031a013.

23. Marenich, A.V.; Cramer, C.J.; Truhlar, D.G. Universal solvation model based on solute electron density and a continuum model of the solvent defined by the bulk dielectric constant and atomic surface tensions. J. Phys. Chem. 2009, B113, 6378-6396, https://doi.org/10.1021/jp810292n.

24. Brandán, S.A.; Díaz, S.B.; Cobos Picot, R.; Disalvo E.A.; Ben Altabef, A. Hydration of inorganic phosphates in crystal lattices and in aqueous solution. An experimental and theoretical study. Spectrochim. Acta Part A 2007, 66, 1152-1164, https://doi.org/10.1016/j.saa.2006.05.029.

25. Rauhut, G.; Pulay, P. Transferable Scaling Factors for Density Functional Derived Vibrational Force Fields. J. Phys. Chem. 1995, 99, 3093-3100, https://doi.org/10.1021/j100010a019.

26. Sundius, T. Scaling of ab-initio force fields by MOLVIB. Vib. Spectrosc. 2002, 29, 89-95, https://doi.org/10.1016/S0924-2031(01)00189-8.

27. HyperChem ${ }^{\circledR}$ is a registered trademark of Hypercube, Inc.

28. Nielsen, A.B.; Holder, A.J. Gauss View 5.0, User's Reference, GAUSSIAN Inc., Pittsburgh, PA, 2008.

29. Frisch, M.J.; Trucks, G.W.; Schlegel, H.B.; Scuseria, G.E.; Robb, M.A.; Cheeseman, J.R.; Scalmani, G.; Barone, V.; Mennucci, B.; Petersson, G.A.; Nakatsuji, H.; Caricato, M.; Li, X.; Hratchian, H.P.; Izmaylov, A.F.; Bloino, J.; Zheng, G.; Sonnenberg, J.L.; Hada, M.; Ehara, M.; Toyota, K.; Fukuda, R.; Hasegawa, J.; Ishida, M.; Nakajima, T.; Honda, Y.; Kitao, O.; Nakai, H.; Vreven, T.; Montgomery, J.A.; Peralta, J.E.; Ogliaro, F.; Bearpark, M.; Heyd, J.J.; Brothers, E.; Kudin, K.N.; Staroverov, V.N.; Kobayashi, R.; Normand, J.; Raghavachari, K.; Rendell, A.; Burant, J.C.; Iyengar, S.S.; Tomasi, J.; Cossi, M.; Rega, N.; Millam, J.M.; Klene, M.; Knox, J.E.; Cross, J.B.; Bakken, V.; Adamo, C.; Jaramillo, J.; Gomperts, R.; Stratmann, R.E.; Yazyev, O.; Austin, A.J.; Cammi, R.; Pomelli, C.; Ochterski, J.W.; Martin, R.L.; Morokuma, K.; Zakrzewski, V.G.; Voth, G.A.; Salvador, P.; Dannenberg, J.J.; Dapprich, S.; Daniels, A.D.; Farkas, O.; Foresman, J.B.; Ortiz, J.; Cioslowski, J.; Fox, D.J. Gaussian, Inc., Wallingford CT, 2009.

30. Ugliengo, P. MOLDRAW Program. University of Torino, Dipartimento Chimica IFM, Torino, Italy, 1998.

31. Parr, R.G.; Pearson, R.G. Absolute hardness: companion parameter to absolute electronegativity. Journal of the American Chemical Society 1983, 105, 7512-7516, https://doi.org/10.1021/ja00364a005.

32. Romani, D.; Brandán, S.A.; Márquez, M.J.; Márquez, M.B. Structural, topological and vibrational properties of an isothiazole derivatives series with antiviral activities. J. Mol. Struct. 2015, 1100, 279-289, http://dx.doi.org/10.1016/j.molstruc.2015.07.038.

33. Chain, F.E.; Ladetto, M.F.; Grau, A.; Catalán, C.A.N.; Brandán, S.A. Structural, electronic, topological and vibrational properties of a series of N-benzylamides derived from Maca (Lepidium meyenii) combining spectroscopic studies with ONION calculations. J. Mol. Struct. 2016, 1105, 403-414, https://doi.org/10.1016/j.molstruc.2015.10.082.

34. Chain, F.; Romano, E.; Leyton, P.; Paipa, C.; Catalán, C.A.N.; Fortuna, M.A.; Brandán, S.A. An experimental study of the structural and vibrational properties of sesquiterpene lactone cnicin using FT-IR, FT-Raman, UV-visible and NMR spectroscopies. J. Mol. Struct. 2014, 1065-1066, 160-169, http://dx.doi.org/10.1016/j.molstruc.2014.02.057.

35. M. Minteguiaga, E. Dellacassa, M.A. Iramain, C.A.N. Catalán, S.A. Brandán, A structural and spectroscopic study on carquejol, a relevant constituent of the medicinal plant Baccharis trimera (Less.) DC. (Asteraceae). J. Mol. Struct. 2017, 1150, 8-20, http://dx.doi.org/10.1016/j.molstruc.2017.08.068. 
36. Minteguiaga, M.; Dellacassa, E.; Iramain, M.A.; Catalán, C.A.N.; Brandán, S.A. A structural and spectroscopic study on carquejol, a relevant constituent of the medicinal plant Baccharis trimera (Less.) DC. (Asteraceae). J. Mol. Struct. 2017, 1150, 8-20, https://doi.org/10.1016/j.molstruc.2018.04.001.

37. Boys, S.F. and Bernardi, F. The Calculation of Small Molecular Interactions by the Differences of Separate Total Energies. Some Procedures with Reduced Errors. Molecular Physics, 1970, 19, 553-566. https://doi.org/10.1080/00268977000101561.

38. Keresztury, G.; Holly, S.; Besenyei, G.; Varga, J.; Wang, A.; Durig, J.R. Vibrational spectra of monothiocarbamates-II. IR and Raman spectra, vibrational assignment, conformational analysis and ab initio calculations of S-methyl-N,N-dimethylthiocarbamate. Spectrochimica Acta Part A: Molecular Spectroscopy 1993, 49, 2007-2026, https://doi.org/10.1016/S0584-8539(09)91012-1.

39. Romani, D.; Brandán, S.A. Investigating the behaviors of corticosterone hormone in different solvents by using DFT calculations and experimental data. Biointerface Research in Applied Chemistry, 2020, 10, 48764892, https://doi.org/10.33263/BRIAC101.876892.

40. Noureddine, O.; Gatfaoui, S.; Brandan, S.A.; Sagaama, A.; Marouani, H.; Issaoui, N. Experimental and DFT studies on the molecular structure, spectroscopic properties, and molecular docking of 4-phenylpiperazine-1ium dihydrogen phosphate. J Mol. Struct. $\mathbf{2 0 2 0}, \quad 1207, \quad 127762$, https://doi.org/10.1016/j.molstruc.2020.127762.

41. Márquez, M.J.; Brandán, S.A. DFT study of Species Derived from the Narcotic Antagonist Naloxone. Biointerface Research in Applied Chemistry, 2020, 10, 8096-8116, https://doi.org/10.33263/BRIAC102.096116.

42. Guzzetti, K.A.; Iramain, M.A.; Rudyk, R.A.; Manzur, M.E.; Brandán, S.A. Vibrational studies of species derived from potent $\mathrm{S}(+)$ and $\mathrm{R}(-)$ Ecstasy stimulant by using Ab-initio calculations and the SQM approach. Biointerface Research in Applied Chemistry, 2020, 10, 6783-6809, https://doi.org/10.33263/BRIAC106.67836809.

43. Romani, D.; Noureddine, O.; Issaoui, N.; Brandán, S.A. Properties and reactivities of niclosamide in different media, a potential antiviral to treatment of COVID-19 by using DFT calculations and molecular docking. Biointerface Research in Applied Chemistry, 2020, 10, 7295-7328, https://doi.org/10.33263/BRIAC106.72957328.

44. Ruiz Hidalgo, J.; Brandán, S.A. Structural Study and Vibrational Assignments of Anticonvulsant Topiramate by using DFT calculations and Two Harmonic Force Fields. Biointerface Research in Applied Chemistry, 2021, 11, 9880-9903, https://doi.org/10.33263/BRIAC113.98809903.

45. Ruiz Hidalgo, J.; Brandán, S.A. Theoretical DFT Studies on Free base, Cationic and Hydrochloride species of Narcotic Tramadol Agent in Gas Phase and Aqueous Solution. Biointerface Research in Applied Chemistry, 2021, 11, 13064-13088, https://doi.org/10.33263/BRIAC115.1306413088. 


\section{Supplementary materials}

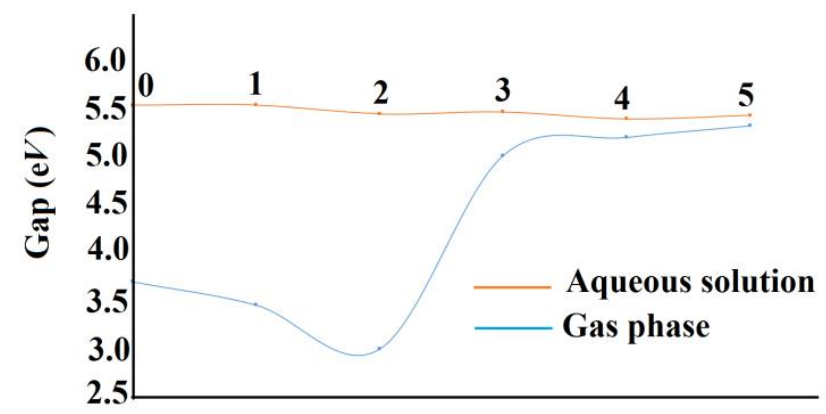

Figure S1. The frontier molecular (HOMO and LUMO) orbitals for the 5-hydroxypentanoyltrifluoroborate $\left[\mathrm{C}_{5} \mathrm{H}_{9} \mathrm{BF}_{3} \mathrm{O}_{2}\right]^{-}$anion and $\left[\mathrm{C}_{5} \mathrm{H}_{9} \mathrm{BF}_{3} \mathrm{O}_{2}\right]\left[\mathrm{H}_{2} \mathrm{O}\right]_{\mathrm{n}}$ clusters, with $\mathrm{n}$ from 1 to 5 water molecules in gas phase and aqueous solution by using the B3LYP/6-311++G** level of theory.
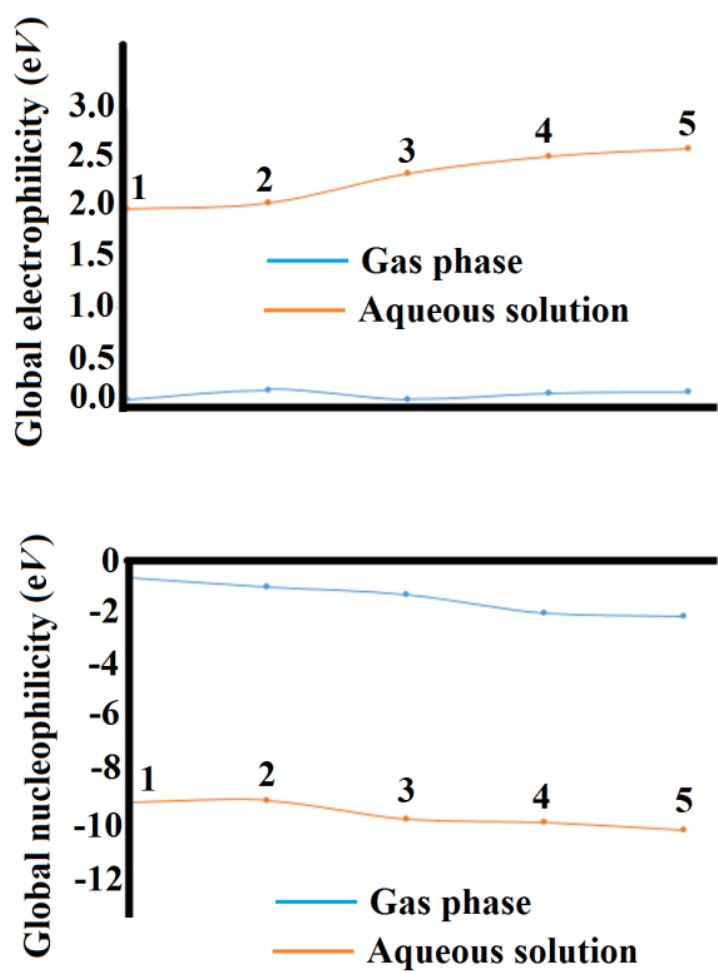

Figure S2. Global electrophilicity and nucleophilicity descriptors for the 5- $\left[\mathrm{C}_{5} \mathrm{H}_{9} \mathrm{BF}_{3} \mathrm{O}_{2}\right]\left[\mathrm{H}_{2} \mathrm{O}\right]_{\mathrm{n}}$ clusters of hydroxypentanoyltrifluoroborate $\left[\mathrm{C}_{5} \mathrm{H}_{9} \mathrm{BF}_{3} \mathrm{O}_{2}\right]^{-}$anion with $\mathrm{n}$ from 1 to 5 water molecules in gas phase and aqueous solution by using the B3LYP/6-311++G** level of theory. 


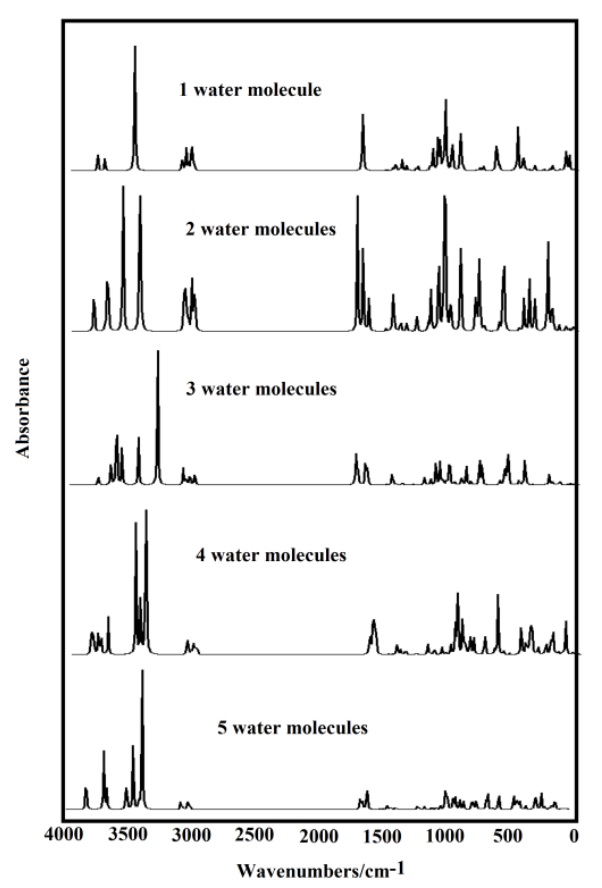

Figure S3. Predicted infrared spectra for the $\left[\mathrm{C}_{5} \mathrm{H}_{9} \mathrm{BF}_{3} \mathrm{O}_{2}\right] \cdot\left[\mathrm{H}_{2} \mathrm{O}\right]_{\mathrm{n}}$ clusters of 5-hydroxypentanoyltrifluoroborate $\left[\mathrm{C}_{5} \mathrm{H}_{9} \mathrm{BF}_{3} \mathrm{O}_{2}\right]^{-}$anion, with $\mathrm{n}$ from 1 to 5 , in aqueous solution by using the B3LYP/6-311++G** level of theory.

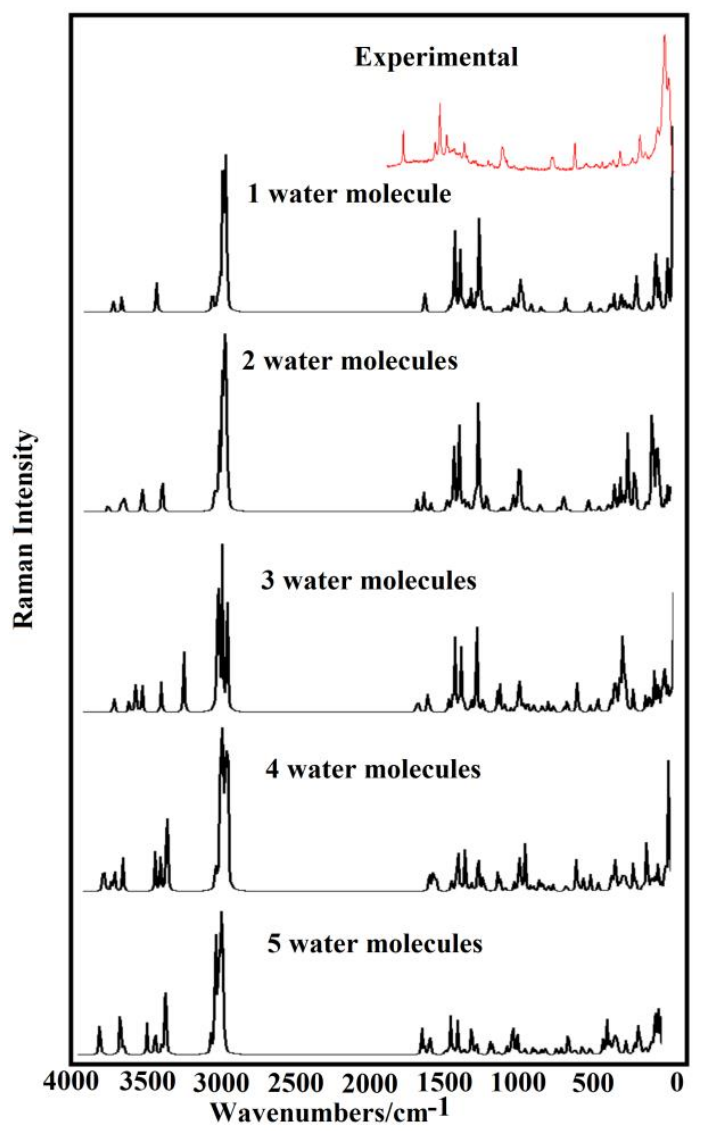

Figure S4. Predicted infrared spectra for the $\left[\mathrm{C}_{5} \mathrm{H}_{9} \mathrm{BF}_{3} \mathrm{O}_{2}\right] .\left[\mathrm{H}_{2} \mathrm{O}\right]_{\mathrm{n}}$ clusters of 5-hydroxypentanoyltrifluoroborate $\left[\mathrm{C}_{5} \mathrm{H}_{9} \mathrm{BF}_{3} \mathrm{O}_{2}\right]^{-}$anion, with $\mathrm{n}$ from 1 to 5 , compared with the corresponding experimental of salt in aqueous solution by using the B3LYP/6-311++ $\mathrm{G}^{* *}$ level of theory. 


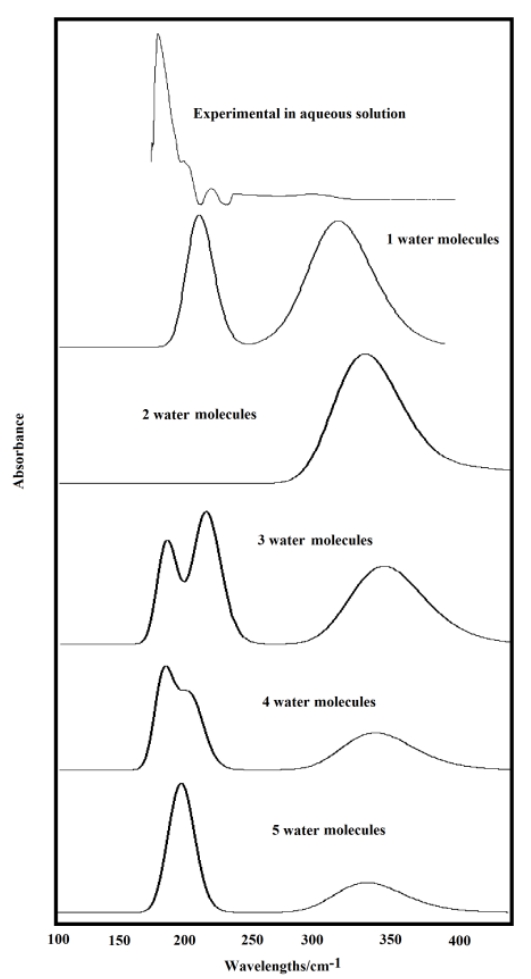

Figure S5. Predicted ultraviolet-visible spectra for the $\left[\mathrm{C}_{5} \mathrm{H}_{9} \mathrm{BF}_{3} \mathrm{O}_{2}\right] \cdot\left[\mathrm{H}_{2} \mathrm{O}\right]_{\mathrm{n}}$ clusters of 5hydroxypentanoyltrifluoroborate $\left[\mathrm{C}_{5} \mathrm{H}_{9} \mathrm{BF}_{3} \mathrm{O}_{2}\right]^{-}$anion, with $\mathrm{n}$ from 1 to 5 , compared with the corresponding experimental of salt in aqueous solution by using the B3LYP/6-311++G** level of theory. 